Татяна ИЛИЕВА

Кирило-Методиевски научен център при БАН София

ilieva_tatyana@abv.bg
UDK 811.163.1'366

Izvorni znanstveni članak

Primljen: 28. svibnja 2019.

Prihvaćen: 19. prosinca 2019.

\title{
АДВЕРБИАЛИЗАЦИЯ И ПРЕПОЗИЦИОНАЛИЗАЦИЯ НА ПРЕДЛОЖНИ СЪЧЕТАНИЯ В СТАРОСЛАВЯНСКИ* ЕЗИК
}

\section{Наречни и полунаречни изрази, образувани посредством предлози със сепаративно значение}

\begin{abstract}
Обект на изследване в статията са наречните и полунаречните съчетания (с непълна лексикализация), образувани чрез сливане в едно словесно цяло на самостойна и служебна дума - предлог в средновековния български език. Изследването е структурирано на класификационен принцип, систематизирайки емпиричния материал според различни критерии - първо в обединения въз основа на участващия при словопроизводството предлог, в рамките на всяко отделно обединение - с оглед на обстоятелството, което означават новообразуваните наречия (за място, време, начин, количество, причина), и най-сетне - на базата на лексико-граматичната принадлежност на мотивиращата дума (съществително, прилагателно, числително, наречие, предлог). Във всеки конкретен случай се анализира пътят на адвербиализацията, проследяват се системните връзки на новообразуваната наречна единица.
\end{abstract}

Ключови думи: старославянски език, лексико-синтактично словообразуване, адвербиализация

Предлаганата статия е част от поредица публикации, в които на базата на ексцерпиран из основните палеославистични лексикографски трудове $^{1}$ материал в диахронен аспект се разглежда лексико-синтактичното

\footnotetext{
* Предвид терминологичните различия, съществуващи в различните славистични школи, възприемам в публикацията това по-общо наименование на първия литературен език на славяните, чиято етническа основа, съотносима с наречието на българските славяни,
} 
образуване на наречия чрез сливане в едно словесно цяло на устойчиви словосъчетания или съчетания на самостойна и служебна дума - предлог. Научният принос на разработката се състои в това, че в нея на базата на предходните изследвания по този въпрос ${ }^{2}$ за пръв път в исторически план

които към втората половина на първото хилядолетие на нашата ера вече населяват югоизточната част на Балканския полуостров, е отдавна установен факт в науката.

1 В изследването се привличат освен лексиката от класическите старослав. паметници (по данни на СС и СтбР) още:

- словният ресурс на старослав. паметници, съхранени в по-късни преписи (по данни на МДРЯ, LLPsl, CЯC);

- речевият фонд на някои среднобългарски паметници (по данни на индекси към отделни произведения от Търновската книжовна школа);

- за сравнение свидетелства от ЦслР, РКБЕНО, днешните диалекти и съвременния български книжовен език.

Широката изворова база е умишлено търсена, тьй като извлеченият от текстове с различна жанрова и хронологична принадлежност материал позволява цялостна визия върху разглежданата категория лексикални единици с оглед на тяхната поява в разнообразни контексти, дава възможност да се обозрат парадигматичните им връзки, по-конкретно синонимията и антонимията като отношения в системата на изследвания словен регистьр, да се уловят общоезиковите словообразувателни тенденции в синхрония и диахрония.

2 В палеославистичната наука тази категория думи е била обект на изследване нееднократно. Преглед на словообразувателните средства и принципи за създаването на наречия в историята на славянските езици, между които и българския, предоставят различните исторически граматики (MIKLOŠIČ 1899; LESKIEN 1919; MILETIČ 1946; MEILLET 1951; VAJAN 1952; LUNT 1955; KUZNECOV 1956; BUSLAEV 1959; BORKOVSKIJ; KUZNECOV 1963; MIRČEV 1963; AITZETMÜLLER 1978; DOBREV 1982; DURIDANOV 1993; SLAVOVA 2017) и др. Поради неизбежните ограничения в обема на съответните ръководства обаче този активен, твърде сложен и многостранен процес не е обхванат от съставителите им в неговата действителна мащабност обстоятелство, което неминуемо е рефлектирало на времето и върху качеството на отразяване на феномена адвербиализация в трудовете по историческа лексикография на славянските езици. Твърде остаряла вече е и монографията на Ал. Дорич за употребата на старослав. наречие, публикувана на немски език през далечната 1910 година (DORITSCH 1910). В по-ново време от различни гледни точки тази категория думи е разглеждана в отделни публикации на редица слависти-медиевисти (VELČEVA 1964; JAN 1967; MOSZYŃSKI 1976; ČURMAEVA 1980; HARALAMPIEV 1980). Специално място темата заема в работите на Ефимова (EFIMOVA 1989.a; EFIMOVA 1989.b; EFIMOVA 1989.c; EFIMOVA 1991.a; EFIMOVA 1991.b; EFIMOVA 2006). В своята кандидатска дисертация изследователката съставя изчерпателен списьк на пълнозначните наречия в стсл. език, анализира връзките им с другите части на речта и въз основа на тези данни определя начините на речепроизводство при тази категория думи, както и основните словообразувателни типове наречия, разглежда въпроси на тяхното функциониране в езика на стсл. ръкописи (EFIMOVA 1989.b). 
с оглед развоя на българския език е представено многоаспектно описание на процеса на адвербиализация от гледище на неговите функционалнограматически механизми. Обстойно се проследява ходът на формиране на един от сегментите на старославянската лексика - образуването на наречия на базата на други части на речта, с техния последващ преход в категорията на служебните думи, определя се ролята на морфологичносинтактическия способ в продуцирането на adverbia и тяхното място в системата на частите на речта в аспекта на взаимоотношенията им с другите класове думи.

Изследването е структурирано на класификационен принцип, систематизирайки емпиричния материал според различни критерии първо в обединения въз основа на участващия при словопроизводството предлог, в рамките на всяко отделно обединение - с оглед на обстоятелството, което означават новообразуваните наречия (за място, време, начин, количество, причина), и най-сетне - на базата на лексикограматичната принадлежност на мотивиращата дума (съществително, прилагателно, числително, наречие, предлог). За всеки адвербиален израз се посочва пълнозначният компонент в състава му с неговото значение ${ }^{3}$ семантиката на лексикализираното съчетание и илюстративен пример за контекстуална употреба от привлечените в изследването лексикографски справочници с указване източника на ексцерпция. Привеждат се и гръцките съответствия на разглежданите лексикални единици (когато откъсът е от преводен текст). Във всеки конкретен случай се анализира пътят на адвербиализацията, проследяват се системните връзки на новообразуваната наречна единица. Наблюденията върху лексикализираните предложни изрази в исторически план се паралелизират с изследването на Ст. Георгиев върху наречната система в съвременния български книжовен език (GEORGIEV 1976).

На следващите страници ще спра вниманието си върху наречните и полунаречните изрази, образувани чрез предлози със сепаративно значение в старослав. език.

Въпреки систематичността и задълбочеността на изследването, то обхваща материал от ограничен кръг паметници, принадлежащи към класическия старослав. корпус предимно сакрални текстове, еднородни по съдържание и жанрова характеристика, което неминуемо редуцира и фрагментира перспективата на филологическото изследване.

3 Целта на тази информация е разкриване на смисловите изменения, настъпващи в процеса на адвербиализация. 


\section{1. НАРЕЧИЯ И НАРЕЧНИ ИЗРАЗИ С ПРЕДЛОГ ИЗТ}

Засвидетелстваните в средновековните писмени паметници наречия, образувани в резултат на предложно-именно лексикализиране с участието на предлог изъ и пълнозначна дума, в старославянския език са продуктивна и твърде многообразна група по отношение на принадлежащите към нея производни лексеми. По този начин са продуцирани адвербиални съчетания за място, време и качество. В процеса на адвербиализация препозицията често пьти изгубва изначалната си локална семантика за посока на действието отвътре навън, като в зависимост от думата, с която се съчетава, се стига до многообразен семантичен резултат. Пораждат се нови семантични признаци като степен, пълнота и обхват, моменталност и др. Някои синтагми формират значение на качество, каквото не се съдържа в изходното съчетание, а е резултат на неговата адвербиализация. Редица от адвербиализираните изрази с предлог изъ в състава си се синонимизират със съответните наречни синтагми, произведени посредством другите сепаративни предлози в старославянски - отт и сты, а се противопоставят на такива с предлог въ, съчетан със същата дума.

\section{1. Наречия за място}

Мотивирани са от нарицателни имена за пространствени понятия, прилагателни, други наречия, предлози. Препозицията се включва във формалната и семантичната структура на съответния лексикализиран израз със своето значение за отделяне или ограниченост на пространството. Наречията се свързват с глаголи за дейност и състояние, за движение и положение в пространството, за определеност по място.

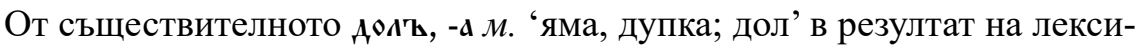
кализация на предложно-именно съчетание се образува наречието издола

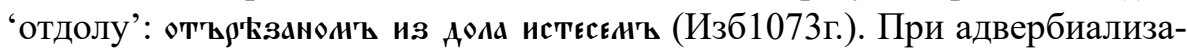
цията на израза се наблюдава промяна в семантиката на мотивиращата дума от по-конкретно към по-обобщено абстрактно значение на 'място, разположено по-ниско спрямо ориентира', нвб. издолу, издол диал.

Към нарицателното пөд' $\mathbf{b},-\mathbf{d} \mathcal{M}$. 'под, долна хоризонтална част на зда-

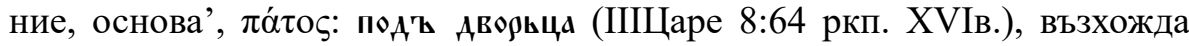
наречието испода 'отдоЛУ': ни постєль испода, ни покрова сть горы (ЖитНик /МинЧетАпр/), vंлока́ $\tau \omega \theta \varepsilon v$. Обликът исподи предполага наличието в езика на морфологичен дублет по $i$-основи *поды, -и ж. или директ- 
но заемане на окончанието -и по аналогия с други наречия, възхождащи към лексикализирани предложно-именни съчетания на съществителни от този склонитбен тип. Срв. искони, изжтри. Би могъл да се предположи и друг път на развитие - през междинна адвербиализация на косвена падежна форма на *поды, -и ж. - поди със значение 'долу', т. е. като резултат от съчетаване на предлог с наречие: оть вєздны источьникъ исподи (ВТз 33:13 ркП. ХІVв.); кыхон'ъ исподи а не вөьхоу (ПАХІв. / ПандАнтХІв./), vंлока́ $\tau \omega, \kappa \alpha ́ \tau \omega \theta \varepsilon v$. Обликът исподъ се обяснява с установяване на една генерализирана форма, която не се променя според рекцията на предлога в съчетанието. Докато испода все още не е изгубило характера си на свободно и пълнозначно съчетание, исподъ вече е претърпяло пълна адвербиализация и последваща препозиционализация (несамостойна употреба + р.п.) със съпътстващите ги морфологични промени: исподт зєлли мизоу (Йер 31:35 ркп. от XIV в.). Участващият в състава сепаративен предлог привнася допълнително значение за отделяне, отдалечаване от място по-ниско от ориентира, произв. исподьнии, нвб. изпод.

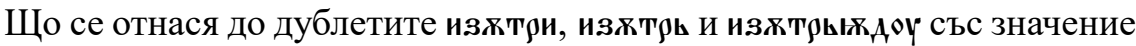
'извътре', първият от тях възхожда към лексикализирано свободно съчетание на предлога из със съществителното втрь, -и ж. 'вътрешност', а вторият и третият са резултат от сливането на сыщия с наречията жт $\mathbf{ь}$ (неизменяема форма на изходното име, функционираща и като прилагателно, и като адвербиум) и жтрыждоу 'вътре', които имат значение на статичност, ограничено пространство според ориентацията към даден предмет. Предлогът преустройва значението на мотивиращите наречия за място, като прибавя към тях нови признаци и модифицира семантичната им структура в посока към два аспекта: за местонахождение в определени граници и за отделитеЛност: цЈкви издобрєны вєзГода канєниєнь,

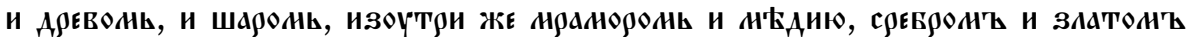

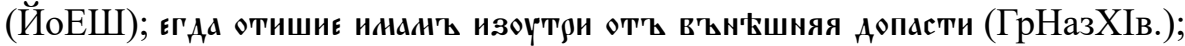

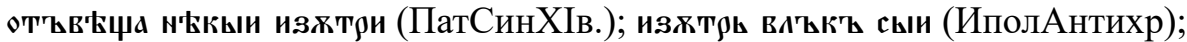

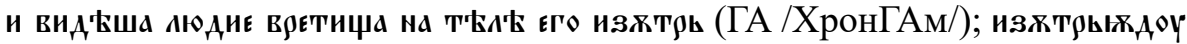

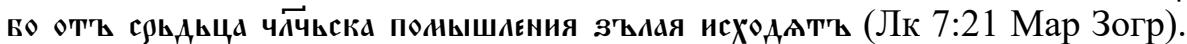
Срещат се и дублетите извънжтри (Лв 14:41) и извънжт ь (Мк 7:23), образувани от срастване на предлога изъ със съставните наречия въмктеи и вънжтрь. Антонимизират се със съответните наречни съчетания с пред-

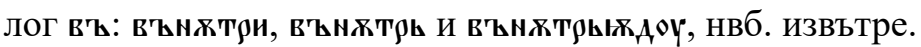

Лексикализираната предложно-именна синтагма изъ сюждюу 'изсред’, която има значение за отделяне спрямо дадена част от ориентиращия 
предмет, приемана в известен смисъл за негова среда, стои по-често до съществително име в р.п., означаващо ориентиращия предмет. Оттук и по-силната предложна функция на това наречие и по-слабо изразеното

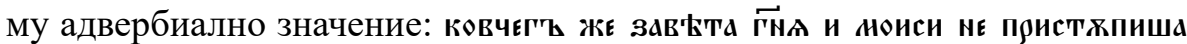
и-с-р६доү плъка (Числа 14:44 ркп. ХVв.). Антонимизира се със съответ-

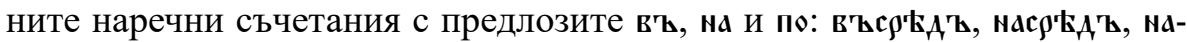

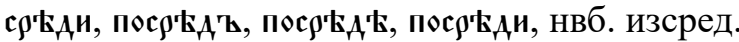

Специфична допълнителна интензифицираща семантика 'от най-вътрешната част на нещо' има наречният израз из д'ъмоү, мотивиран от съ-

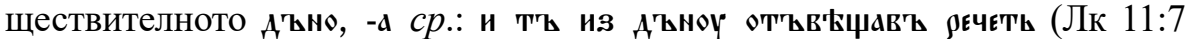
Ев.ХІІв.). При адвербиализацията се наблюдава промяна в семантиката на изходната синтагма от конкретна за място ('отделяне от най-отдалеченото от началото или входа място на някакво пространство') към абстрактна за

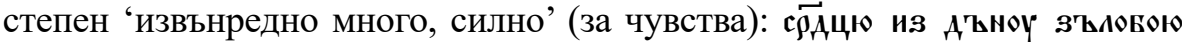
голащоү (Мъчение на Тадей /МинЧетФевр/), нвб. издън поет.

Първоначално неизменяемото прилагателно миць 'който е с лице надолу, към земята', приело впоследствие падежни окончания по аналогия със склоняемите adjectiva, е мотивиращата пълнозначна дума в адвербиализирания предложен израз изница, засвидетелстван в устойчивото съчетание изница възияды 'Гледайки изпод око, крадешком, скришом' (Супр). Тук се наблюдава допълнителна вторична промяна на адвербиалното значение с обстоятелствен признак за място към качествено-определителна семантика, нвб. срв. изничам диал.

Аналогичен е случаят и при наречния израз издылєча 'отдалече', в чиято основа стои прилагателното Адлєчь 'далек, далечен': почьто ндыd А'大ля

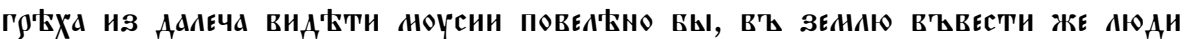

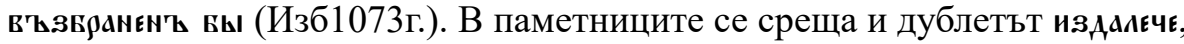
получен при сливането на предлога из с простото наречие дахєчє. Препозицията преустройва значението на мотивиращия адвербиум за място, като прибавя към него нови признаци и модифицира неговата семантична структура в посока към два аспекта: за местонахождение на отстояние и за отделителност:

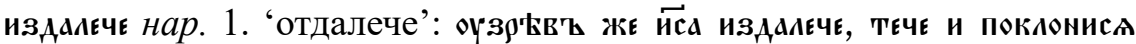

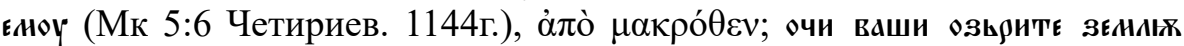

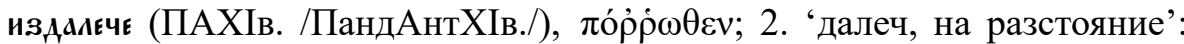
сташа издалєчє (Лк 1:12), нвб. издаЛече, издаЛеч.

Развитието на значението за статичност води до синонимизиране на

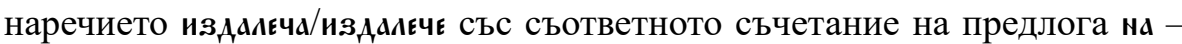




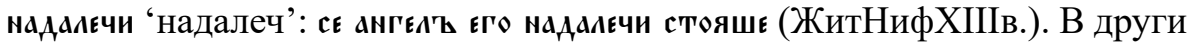
контексти сьщите адвербиални изрази се антонимизират, противопоставяйки се по признака посока от и към ориентиращия обект.

Идентичен в структурно-семантично отношение с наречието издалече 'отдалеч' е неговият антоним извлизоү 'отблизо' (Микл), резултат от срастване на разглежданата препозиция и простия адвербиум влизоү.

От сливането на предлог из с наречията въьноу (възхождащо към засвидетелствано само в адвербиализирани падежни форми, но не и в им.п. съществително име *в'ьн'ъ) и в'ьнждау са се получили производните из-

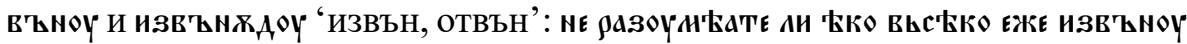

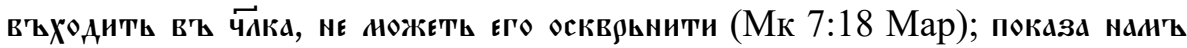

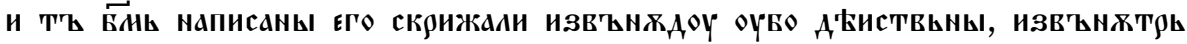
жє видьны (Супр), ह̌ $\xi \omega \theta \varepsilon v$. В този случай функцията на предлога из може да се определи като обновителна. Същият допълнително експлицира вътрешно присъщата сепаративна семантика на изходното наречие в'ъноү и въмкдау, без да привнася някаква промяна в значението. За въноү и извъьно е характерна и несвободна употреба заедно с местоимение или име в р.п., като предлози, нвб. извън.

\section{2. Наречия за време}

В лексикализирани съчетания с пълнозначна дума, назоваваща пряко времево понятие като оүтро или имаща в семантичната си структура признаци, близки до признаците за време (нпр. съществителните стаяина 'древност' и өтрочина 'детство', прилагателните новъ и давьн'ъ, числителното прьвъ), предлогът из означава момента, периода или срока, от който насетне се извършва действието.

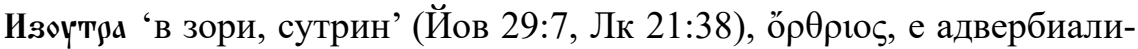
зирано съчетание на предлога из със съществителното име оүтрө, -д ср. То се отнася към групата на опосредованите наречия, които придобиват своето значение, свързвайки темпоралната даденост с някакво измерение за време (в случая ден). Предлогът, участващ в словообразуването, внася един от характерните за него семантични нюанси да посочва ограниченост във времето.

Конкретно съществително - наименование на телесна част - с характерната за процеса на адвербиализация промяна на предметното значение към по-обобщено обстоятелствено за време мотивира лексикализираното 


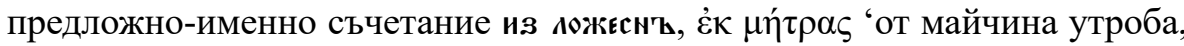

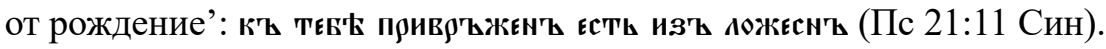

Етимологията на наречието искони, изразяващо пределност на започване на действието - отначало, открай време - се извежда от срастване между предлога из и старо съществително *kanь, kanъ със значение 'на-

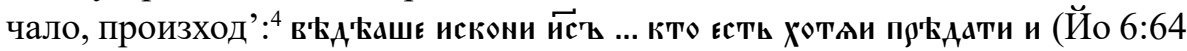
Мар, Зогр, Ас, Сав). Същото много често се отнася за състояние на лице, поради което се съчетава предимно с глагола 'съм': искони в'Еашє слово

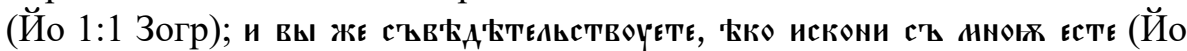

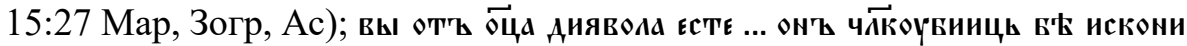
(Йо 8:44 Мар, Зогр, Ас), нвб. искони остар. книж.

С близко значение до искони е лексикализираният израз из ндчАл 'от-

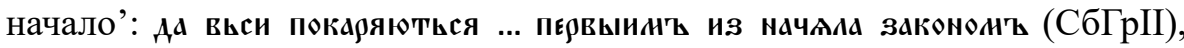

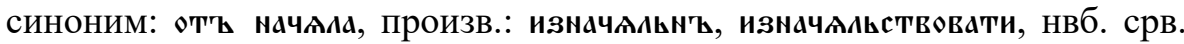
изначален.

Наименования на периоди от човешкия живот мотивират близкозначните наречни съчетания из д'Етьства и из отрочины 'от детство': и

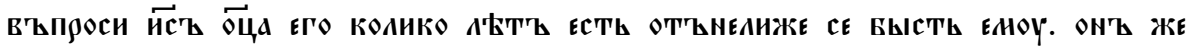
९єчє изъ отрочины (Мк 9:21 Мар). Синонимни на тях са образуваните от

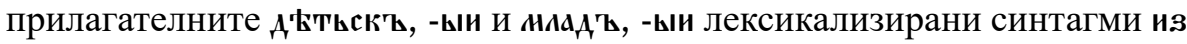

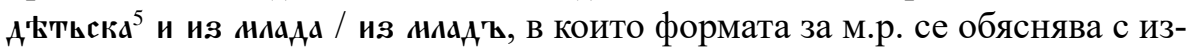
пуснато мъжкородово име - възздста 'възраст'. Засвидетелстван е също

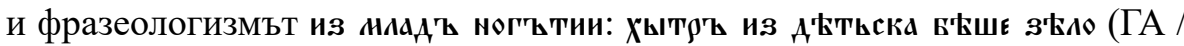

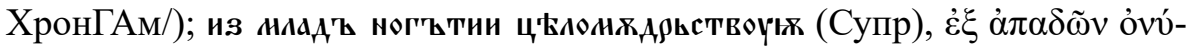

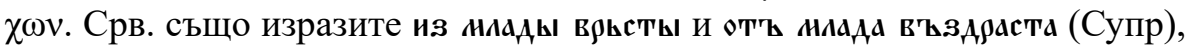
нвб. срв. от детска възраст, от детство.

Съществително с абстрактно значение е в основата на засвидетелствания в късни паметници адвербиализиран израз из старины 'отдавна' - за голямо отстояние назад във времето без точно определяне на началния момент. Същото значение има и слятото съчетание издавьна 'отдавна', възхождащо към прилагателното давьн'ы, -ыи (с подразбиращо се съ-

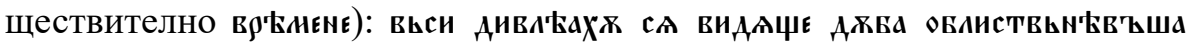

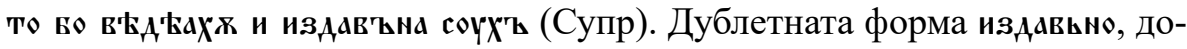

${ }^{4}$ Срв. суфиксалното производно көньць, -д $\mathcal{M}$. (БЕР 2, 33).

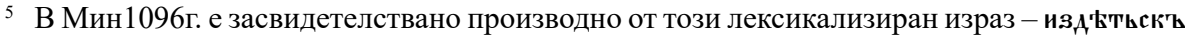

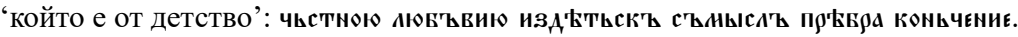


кументирана в късни паметници, се извежда от простото наречие давьно, нвб. издавна остар. книж.

БЛизкозначно на горните е наречието издљєвлє, образувано от сраства-

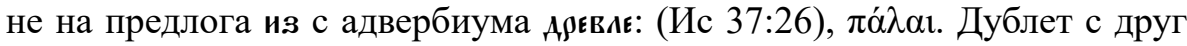
сепаративен предлог е отыдљєвлє.

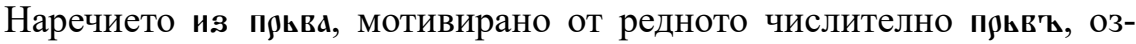
начава началния момент в реда от последователност на моменти в два основни аспекта - безотносително и в отношение спрямо момента на

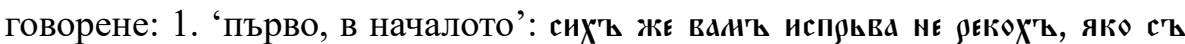

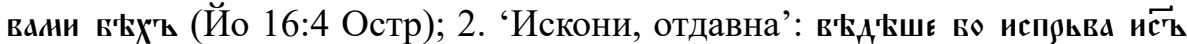

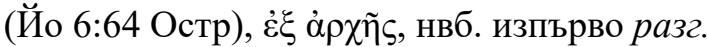

Преносно за изразяване на времеви отношения 'започване или завършване на действието в близост до ориентационния момент' се използва и наречието изьлизоу 'скоро' с първично пространствено значение: изьлизоү излию гн'вь' нои на та (Йез 7:8 ркП. ХІVв.).

\section{3. Наречия за качество и начин}

В някои случаи се наблюдава промяна на конкретно-предметното, респ. обстоятелствено-пространственото, значение на изходното съчетание към по-обобщена качествена семантика на новата синтагма:

Към групата на лексикализираните предложно-именни обединения, мотивирани от съществителни имена - наименования на телесни части, принадлежи наречният израз изоүстъ 'по памет': оүчдсл к'ънигдн'ъ из оу-

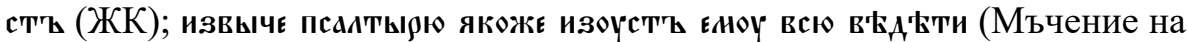
Тадей /МинЧетФевр/), произв. изоүстьнъ, нвб. наизуст.

Към същата група се отнася и наречието излжчь 'ръчно, ръкопашно':

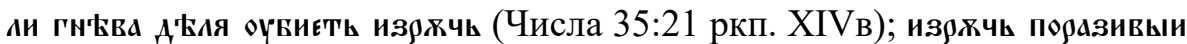

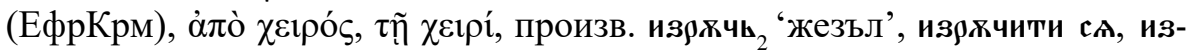
९дчєниє, нвб. изръч, изръце диал.

Към категорията наречия за качество и начин с предлог из, мотивирани от съществително, се числи и изразът из мєзыпы 'ненадейно': вдари ма нихъ из мєздпы (ИпЛ). Мотивировката като признак в значението на наречието се свързва с възникването на действието като случайно, непредвидено. Синоними: въмєздап,, въмезадпъ, нвб. срв. изнезапици диал.

Наречието издялдь 'извънредно' принадлежи към групата на неизменяемите прилагателни със стара $i$-основа, които функционират често като предикативни имена, нпр. влизь, искеь, ниць, осовь, пютнь и др. (DU- 


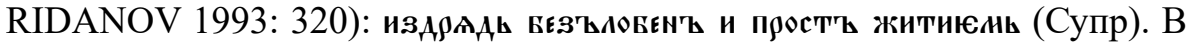
старите писмени паметници са засвидетелствани няколко производни от

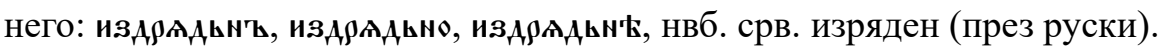

Към категорията наречия за качество и начин с предлог из, мотивирани от прилагателно, ще отбележа още истиха 'тихо, спокойно, незабелязано' (Прол. ноем. 4), излєгъка 'излеко, полека, несилно' (излєгка п'Тти Тп. л. 409 , гр.) и исты'ъста 'издебело, с дебел глас' (Прол. окт. 8). Последните две всъщност са адвербиализирани определителни синтагми с елипса на сьществителното гласт.

\section{4. Наречия за количество}

Като наречия за количество могат да се определят адвербиализираните предложни изрази:

из овила (< овил'ъ, -ыи прил.) / изобиль (< овиль нар. $)^{6}$ 'в изобилие':

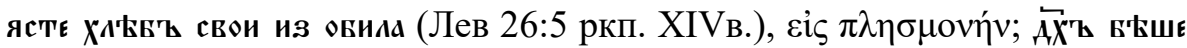
из овила вһ нень (Дан 6:7); изовиль Гостиття словесныли врашны (ЖИТСтефПерм), ПроиЗВ. изовилиє, изовияити, изовиловати, изовильн'ъ, изоБиАьн'Е, изовильствовати, Нвб. срв. изобилно;

из лиха (< иихъв, -ыми прил.) 1. 'Повече, твърде': они жє изт лиха в'ъпияхоу (Мт 27:23 Остр); 2. 'много, извънредно': көњпъкъъ излиха (ИполАнтихр);

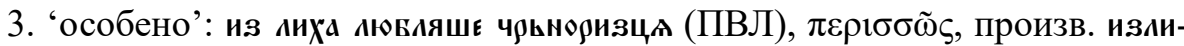

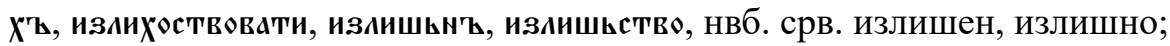

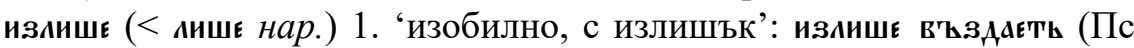
30:24), $\pi \varepsilon \rho 1 \sigma \sigma \tilde{\varsigma} \zeta ; 2$. 'твърде много, прекомерно': ни нждри сл излишє, $\pi \varepsilon$ -

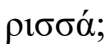

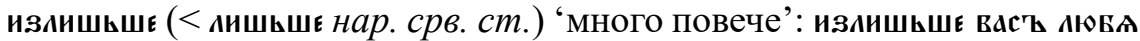

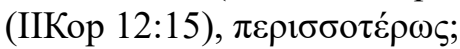

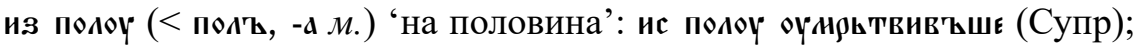

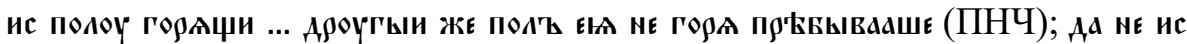

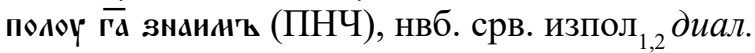

Тук също се наблюдава развитие на по-обобщена качествена семантика.

6 Този облик принадлежи към групата на неизменяемите прилагателни със стара i-основа, които функционират често като предикативи, например влизь, искөь, ниць, осовь, пртни и др. (DURIDANOV 1993: 320). 


\section{2. НАРЕЧНИ И ПОЛУНАРЕЧНИ ИЗРАЗИ С ПРЕДЛОГА ОТЪ}

Предлогът отъ участва в словообразувателния процес на адвербиални изрази със своето основно, отделително значение, разбирано и в по-широк общ смисъл на отнесеност на действието по място, време или признак към някакъв пункт като изходна база, начало. Препозицията има големи съчетателни възможности по отношение на мотивиращите думи -пълнозначни и служебни. Редица от адвербиализираните изрази с предлог отъ в състава си се синонимизират със съответните наречни синтагми с другите два сепаративни предлога - изъ и сты, а се противопоставят на такива с предлог въъ, съчетан със същата дума.

2.1. Наречни и полунаречни изрази с предлог отъь и пълнозначна дума

\subsection{1. Наречни и полунаречни изрази за място}

Мотивирани са от нарицателни имена за пространствени понятия, прилагателни, други наречия, предлози. Препозицията се включва във формалната и семантичната структура на съответния лексикализиран израз със своето първично значение за място, където произтича насочено навън действие или се отделя, откъсва нещо.

От съществителното гора, -ы ж. 'планина' в резултат на лексикализация на предложно-именно съчетание се образува наречието отъ гөяы. При адвербиализацията на израза се наблюдава промяна в семантиката на мотивиращото съществително от по-конкретно към по-обобщено абстрактно значение на 'място, разположено по-високо спрямо ориентира':

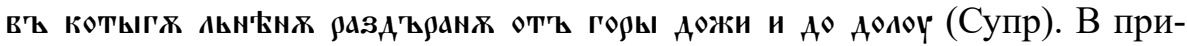
ведения пример е налице контекстуално обединяване на две наречия за място, произведени съответно от сливане на предлозите отъ и до с антонимизиращи се пълнозначни думи, означавали първоначално противоположни посоки, респ. крайните предели на разстояние в пространството - изходната и достигнатата точка (векторни антоними), а след лексикализацията - също и пълнота, завършеност на действието. Характерно е

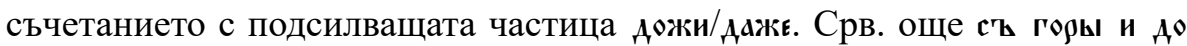
Аола (ЖитНифХІІІв.), нвб. отгоре, отгор (съкр. диал).

От сливането на предлог отъ с наречията въмоү и въънддоү са се по-

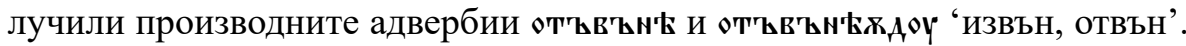
Използват се както с глаголи за движение, така и с такива за статично 


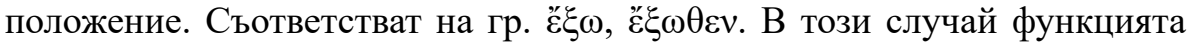
на предлога өтъ може да се определи като обновителна. Същият допълнително експлицира вътрешно присъщата сепаративна семантика на изходното наречие в'ъn'大 и в'ъn'大лдоу, без да привнася някаква промяна в значението. За от'ъв'ън'大 е характерна и несвободна употреба заедно с местоимение или име в р.п., като предлог. Синонимизират се с извъноү и изв'ънкАОУ, НВб. ОТВъН.

В основата на наречния израз отъддаєча 'отдалече' стои първоначално неизменяемото прилагателно дамєчь 'далек, далечен' (Иов 36:3). В паметниците се среща и дублетьт отъдыdєчє, получен при сливането на предлога отъ с простото наречие далєчє. Препозицията преустройва значението на мотивиращия адвербиум за място, като прибавя към него нови признаци - за местонахождение на отстояние и за отделителност.

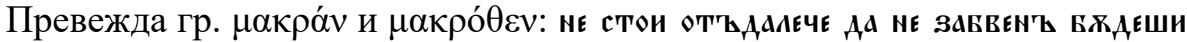
(Сир 13:13).

Към групата на лексикализираните предложно-именни слияния, мотивирани от съществителни имена - названия на телесни части, принадлежи изразът отт иица 'пред, от'. Същият се употребява несамостойно в комбинация с име в р.п. за притежание, конкретизиращо ориентиращия предмет, т.е. като несъщински предлог. При процеса на препозиционализация (синтактична употреба на адвербиализираната синтагма като предлог) става промяна на конкретно-предметното значение на изходното съчетание към по-обобщена обстоятелствена семантика за локално и причинно-следствено отношение: трєпєтати отт иица єго. Синонимизира се със съответното съчетание на предлога съ.

От неизменяемо прилагателно със стара $i$-основа е мотивирано наречието от'ъвюьнь 'напротив, обратно' (от един корен с въртя). От първичното значение за обратна посока на движение или разположение се развива вторична семантика, от една страна, за времева повторяемост, а от друга, за качествено различие. Използва се и като вметната дума за изразяване на противоположно твърдение: отвьљьн'ъ достояшє Быти

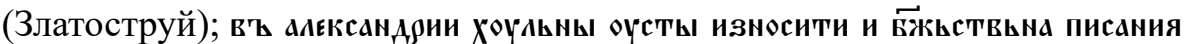

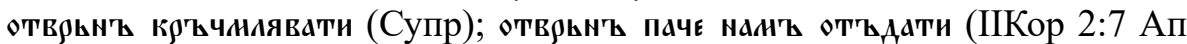

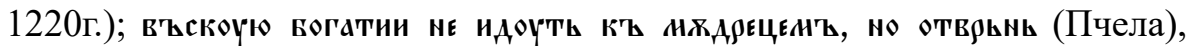
ф̀v $\alpha \dot{\pi} \alpha \lambda \iota v$, нвб. ø.

Наречието өьокдоү и производното му отъ овождоү са образувани от числително име (оьа, оьои) по аналогия с местоименните наречия за място с формант -ждяю, който пьрвоначално е служел за указване на дви- 
жение в определена посока - към или от говорещия, респ. някакъв друг обект (DURIDANOV 1993: 317). Още в старославянски тези отсенки обаче са започнали да се заличават, за което свидетелства съчетаемостта на двете наречия както с глаголи за движение, така и с такива за статичност. Въз основа на първичното значение 'от две страни' за направление или положение се развива вторично за количество - 'двукратно’: нєкли отъ

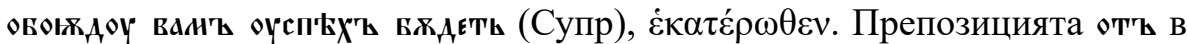
производното предложно съчетание само експлицира определен признак от съдържанието на базата, без да внася допълнителен нюанс в значението ѝ, нвб. ø.

Двойна, дори тройна мотивация може да се предположи при наречното съчетание с несамостойна предложна употреба с д.п. от"ъюлнь 'настрана':

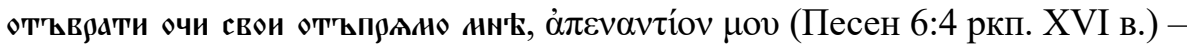
от прилагателното прлыъқ, -ыи. 'прав, право насочен' съответно през неговата адвербиална (пюлм॰ ‘право, пряко’) или предложна употреба (пюлно + р.п. или д.п. със значение 'против'), нвб. срв. прямо, премо.

Наречието схпюотивж е мотивиращата пълнозначна дума в лексикализирания предложен израз от'ьсжпютивж 'от противоположната страна' (ІМак 11:68). Същият образува антонимна двойка с мдсжпюотивж (нвб. наспроти) на базата на противопоставяне по признака посока от и към ориентиращия обект.

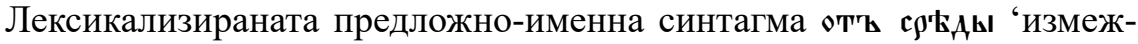
ду', която има значение за отделяне спрямо дадена част от ориентиращия предмет, приемана в известен смисъл за негова среда, стои по-често до съществително име в р.П., означаващо ориентиращия предмет. Оттук и по-силната предложна функция на това наречие и по-слабо изразеното

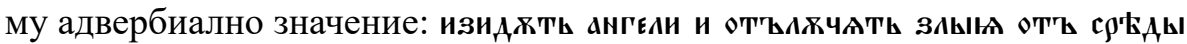
правьдықыныхты (Мт 13:49).

\subsection{2. Наречни и полунаречни изрази за време}

Предлогът өтқ при тези наречни изрази посочва момента за начало на протичащото действие.

Пределност на започване на действието изразява лексикализираната

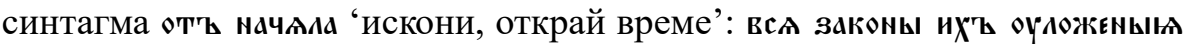

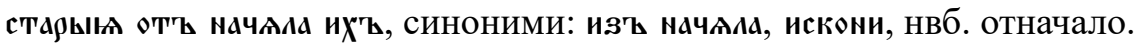

Съществителното вък'ы, - $\boldsymbol{M}$., с което в старославянски се назовава 'дълъг период от време, епоха, вечност', мотивира адвербиализираните 
дублетни съчетания отъ въка / от’ вък' 'открай време, от много от-

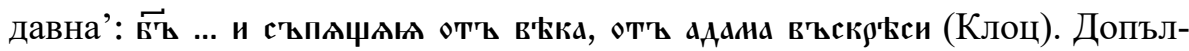
нителен диференциращ признак тук е неразчленеността, постоянната продължителност във времето, противопоставяща се на признака 'прекъснатост в протичането', нвб. отвека поет.

Наречното съчетание өтъ дттьска е мотивирано от прилагателното д tттькъ, -ыи. Формата за м.р. се обяснява с изпуснато мъжкородово име

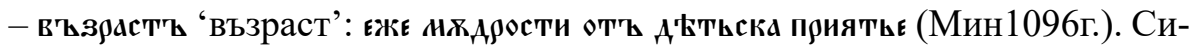
нонимизира се със съответните наречни синтагми, произведени посред-

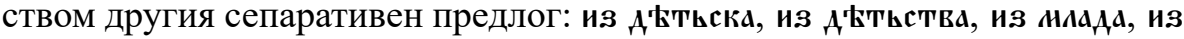
өтрочины, нвб. от детска възраст, от детство, от дете.

При срастване на предлога отқ с първичното наречие ным'(чюу) се е получило съставното наречие отьнынt(чоү) със значение 'от момента, в който се говори, в посока към бъдещето, отсега, занапред’: түньжє и ны

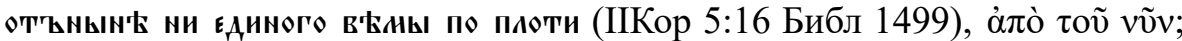

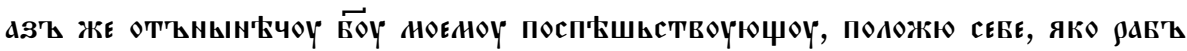
єсни того (ЕфрСир 1377г.), нвб. отнине остар.

Идентични помежду си в структурно-семантично отношение са наречията отъ дъқнога 'от много време' (ЦслР) и отықдавьна 'отдавна' (Прол. дек. 6, Крм л. 142.), мотивирани от пълнозначна дума прилагателно - нъъ-

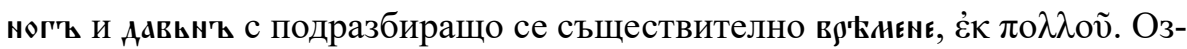
начават неопределена, но голяма отдалеченост на началото на завършило или продължаващо към ориентационния момент действие или състояние: синонимизират се със наречното съчетание с предлог из издавьнд.

Близкозначно на горните е наречието отыдяєвлє, образувано от срастване на предлога отъ с адвербиума дљєвлє (Ак. св. К. и М. ик. 12). Дублет с друг сепаративен предлог е изА९євлє.

Адвербиализираното съчетание на предлога оты със синтагмата дымы сь се отнася към групата на опосредованите наречия, които придобиват своето значение, свързвайки темпоралната даденост с някакво измерение за време (в случая ден). Включеното в състава показателно местоимение внася в семантиката признака определеност. Предлогьт, участващ в словообразуването, добавя характерната за него семантика да посочва началния момент на протичащото действие. 


\subsection{3. Наречия за качество и начин}

В преобладаващата си част лексикализираните предложно-именни синтагми с предлог отъв, принадлежащи към тази категория, са своеобразна семантична трансформация на отделителното значение, свързано с по-абстрактни съществителни:

от чАсти 'частично, в някаква степен': разоүн'всте ны отть чАсти (ПАХІв. / ПандАнтХІв./);

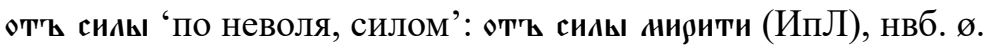

\section{2. Лексикализирани съчетания на предлог отт с прости} местоименни наречия

Отделна група формират лексикализираните съчетания на предлог отъ с прости местоименни наречия. Те могат да се разделят на две групи - самостоятелни и несамостоятелни. Към втората категория спадат относителните, които са поели функцията на подчинителни съюзи.

\subsection{1. Наречия за място}

В старите писмени паметници са документирани различни местои-

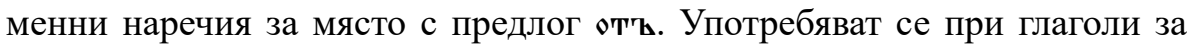
движение в значение 'отделяне на предмет от някакво място, насоченост или ориентираност в определена посока', често пьти с разширение от друг обстоятелствен израз с локативна семантика, въведен от предлозите въz, на или до в значение на придвижване от едно място на друго. Могат да стоят и при глаголи с по-обща каузативна семантика. Тук се отнасят следните корелати:

\subsubsection{1. Дейктични:}

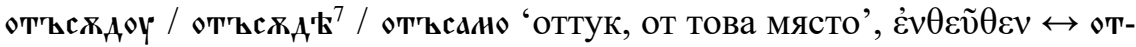

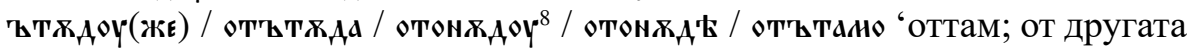

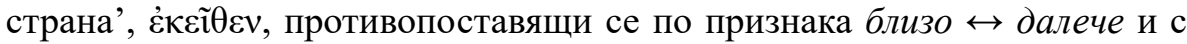
допълнителен признак на насоченост или ориентираност в определена

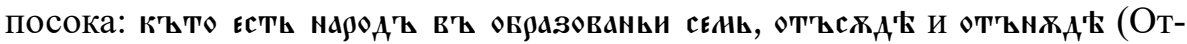
кровение Авраамово); яко гжБа воды отъттдау почьрпє (Мин 1096г.); в'ъс-

\footnotetext{
7 Срещат се сьщо и облиците от"ъсьдє и отздє.

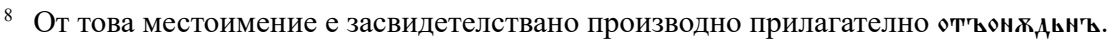




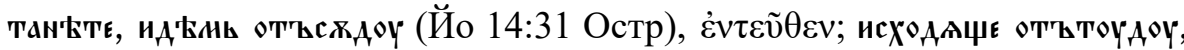

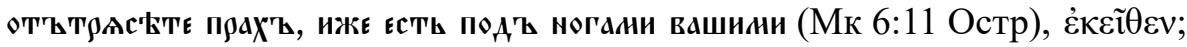

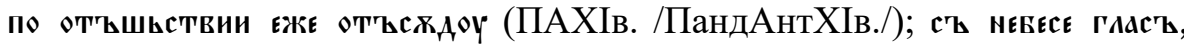

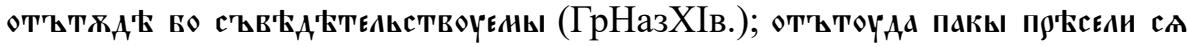
на ин'ъ Ха'ъм'ъ (НестЖитТеод), нвб. отсъд диал.

\subsubsection{2. Въпросителни и относителни:}

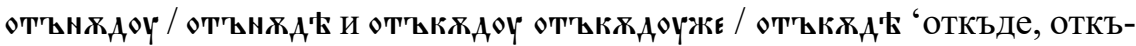

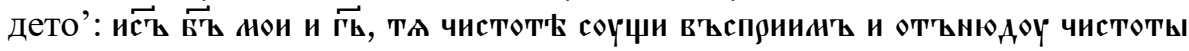

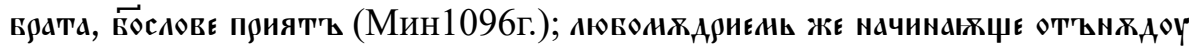

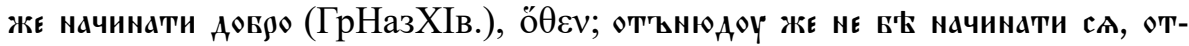

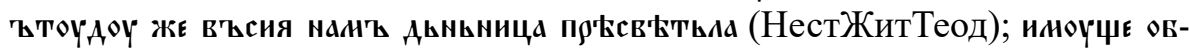

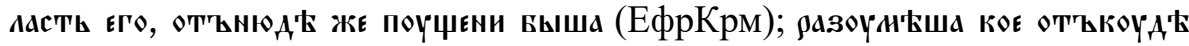

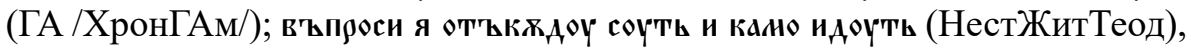
нвб. оттъд диал., откъд диал.

\subsubsection{3. Обобщителни:}

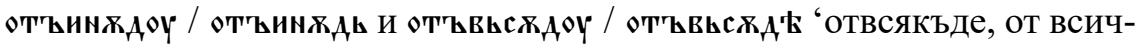
ки страни': тво

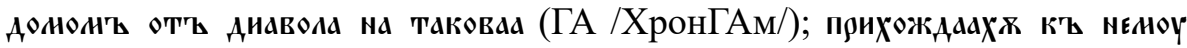

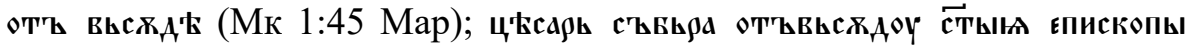
въ никєискыи градт (Супр). Производни от съчетание на предлог отъ с обобщително местоименно наречие, тези наречия имат обобщаваща семантика на отнесеност към много предмети и места или разпръснатост, означават повсеместност, масовост, всеобхватност, сгъстеност, плътност по място, свързват се с представата за сборност на действието, нвб. отнюд, отсъде диал.

\subsubsection{4. Неопределителни}

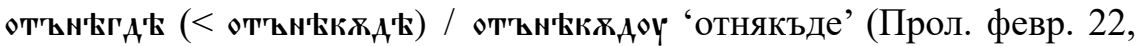

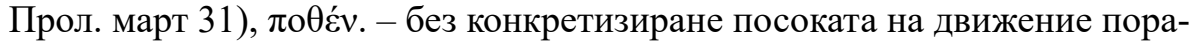
ди неосведоменост.

Локативното значение на горепосочените наречия може да се трансформира в резултат на пренос и в други значения въз основа на заложения признак за отделяне.

- за време:

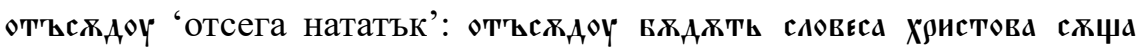
(Супр); 


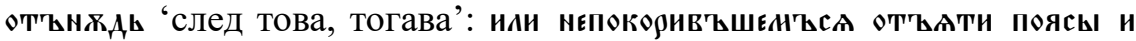

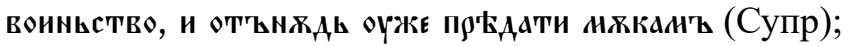

- за причина:

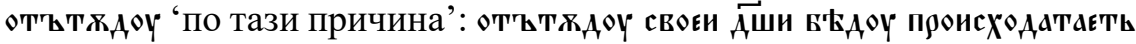
(Грам. п. Нил. 1383г.);

отььондаяюу 'ето защо, затова', ӧ $\theta \varepsilon v$;

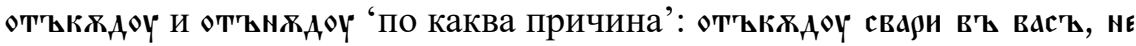

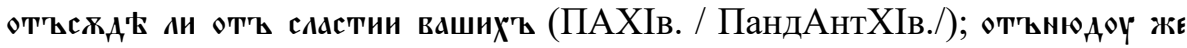
дөяжьнъ єсть (МДРЯ) в късни пам.

С твърде широк семантичен обхват се отличава наречието отъинждюу / отьинжды. Освен отбелязаното вече първично значение за място 'от всички страни' на базата на обобщителната си семантика то развива също значение за степен в количествен и качествен смисъл 'съвсем, съвърше-

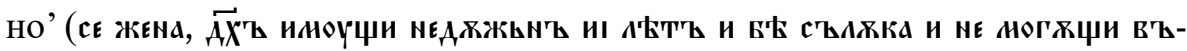

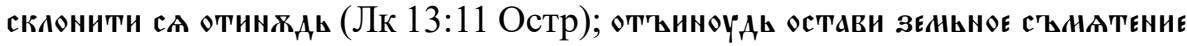
(Мин1097г.) и 'много, твърде': остюови ндли ннози отқинүды (КозмаИнд). Редом с това се употребява и като въвеждаща и уточняваща дума 'изобщо’ или като наречие за неконкретност, недоказаност, немотивираност:

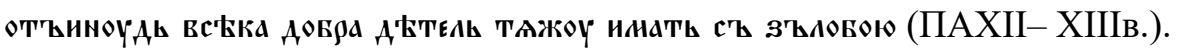

\subsection{2. Наречия за време}

Местоименните наречия за време с предлог оты означават определен времеви момент като начална граница, оттатък която действието не се простира. Образуват корелативни двойки, антонимизиращи се по признака близъкњ далечен момент:

\subsubsection{1. Дейктични:}

отқтоли, отқтол', отқтол 'оттогава, от онзи минал момент, за който

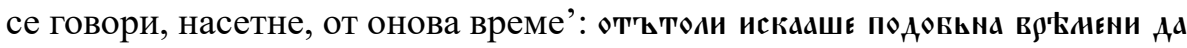

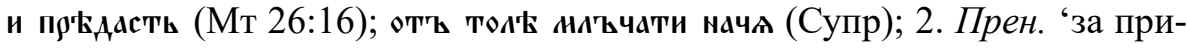

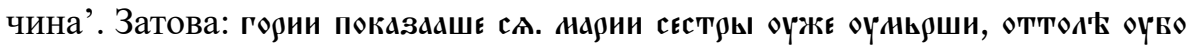

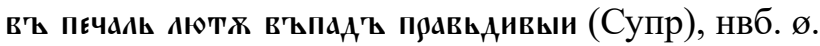

отһсєАћ, отһсєли 1. 'ОТ моменТа, в който се говори, В Посока Към бъдещето, отсега, занапред’: отъсєли оүзлите ньса отъвљьста (Йо 1:52 Ас); отъ-

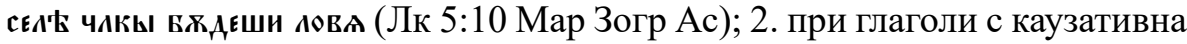
семантика в значение за възникване 'оттук, от това'; вжди жє ни ст Б̈нь 


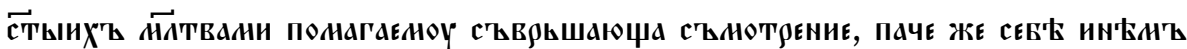
отъсел' АөБ

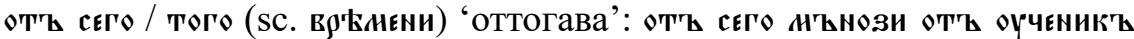

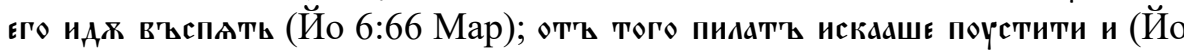
19:12 Мар), нвб. отсега, оттога (диал.)

\subsubsection{2. Относителни:}

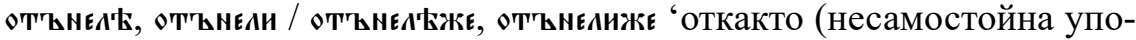

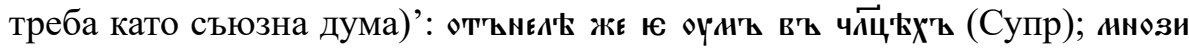

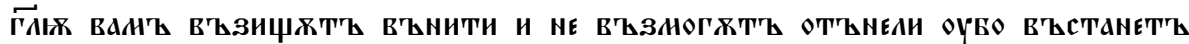

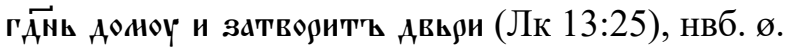

\subsubsection{3. Въпросителни:}

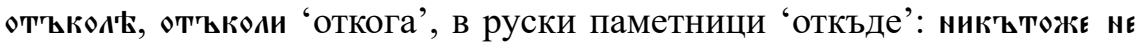

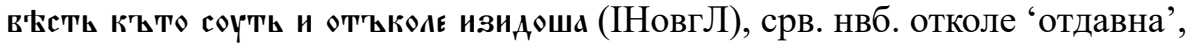
нвб. отколе поет.

\section{3. НАРЕЧНИ И ПОЛУНАРЕЧНИ ИЗРАЗИ С ПРЕДЛОГА ОТ}

С предлог съ продуцирали адвербиални съчетания основно за място, по-малко за време и качество. Препозицията участва в словообразувателния процес на адвербиални изрази със своето основно, отделително значение, разбирано и в по-широк общ смисъл на отнесеност на действието по място, време или признак към някакъв пункт като изходна база, начало. Редица от адвербиализираните изрази с предлог съ в състава си се синонимизират със съответните наречни синтагми с другите два сепаративни предлога

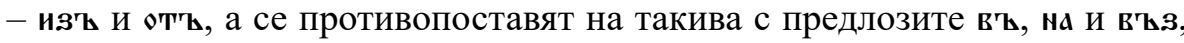
съчетани със същата дума.

\section{1. Наречия за място}

Мотивирани са от нарицателни имена за пространствени понятия, прилагателни, други наречия, предлози. Предлогът ст се включва във формалната и семантичната структура на съответния лексикализиран израз със своето значение за посочване на място като пункт, откъдето изхожда действието, респ. за отделяне от повърхността или движение отгоре надолу. 
От съществителното гора, -ы ж. 'планина' в резултат на лексикализация на предложно-именно съчетание се образува наречието съ голы 'отгоре': съ горы и дө дөла (ЖитНифХІІв.). При адвербиализацията на израза се наблюдава промяна в семантиката на мотивиращото съществително от по-конкретно към по-обобщено абстрактно значение на 'място, разположено по-високо спрямо ориентира'. В приведения пример е налице контекстуално съчетаване на две наречия за място, произведени съответно от сливане на предлозите ст и до с антонимизиращи се пълнозначни думи, означаващи противоположни посоки (векторни антоними) за изразяване пълнота, завършеност на действието. Изразът съ голы е засвидетелстван и в преносна употреба 'свише, от небесата, от Бога':

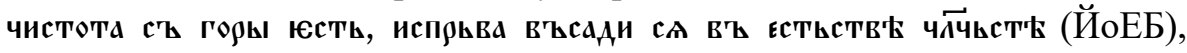
нвб. срв. озгоре (от * от с горе - случай на вторична адвербиализация с плеонастично натрупване на предлози).

Идентично в структурно-семантично отношение с наречието съ голы 'отгоре' е антонимното наречие съ долюү 'отдолу' (Прол. май 11), базирано на съществителното дөл'ъ, -х $\boldsymbol{м}$. При адвербиализацията на израза се наблюдава промяна в семантиката на мотивиращото сыществително от по-конкретно 'вдлъбната земна форма' към по-обобщено абстрактно значение на 'място, разположено по-ниско спрямо ориентира'. Би могъл да се предположи и друг път на развитие - от съществителното дол'ъ през междинното наречие долюу (адвербиализирана падежна форма на изходната дума) до предложно-наречното съчетание съ д долюү с трансформация на значението в сепаративно, нвб. ø. Срв. оздол (от с долу - плеонастично натрупване на предлози) диал. Синонимизира се със съответните адвербии, произведени чрез комбинирането на първичната наречна основа с

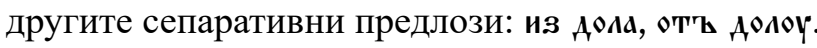

Двойна мотивация може да се предположи и при наречното съчетание

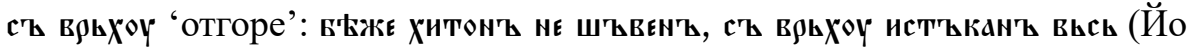

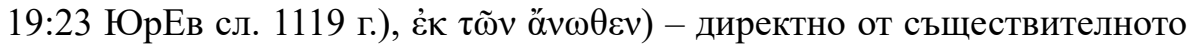

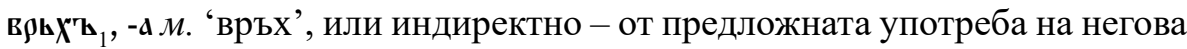
падежна форма (вљьхоу + р.п. 'отгоре на'), т.е. като срастване на два предлога. При лексикализацията на израза се наблюдава промяна в семантиката на мотивиращото съществително от конкретно към абстрактно значение на 'място, разположено по-високо спрямо ориентира'. Засвиде-

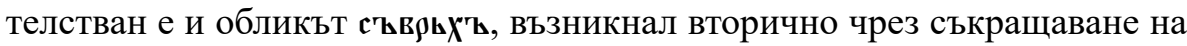
падежната флексия поради нейната десемантизация, нвб. свръх; свръха диал. 
Отделна група обособяват лексикализираните предложно-именни синтагми, мотивирани от наименования на телесни части, с характерното за процеса на адвербиализация изменение на смисъла от предметен към по-обобщен пространствен. Така, от сливането на предлога сты с дублет-

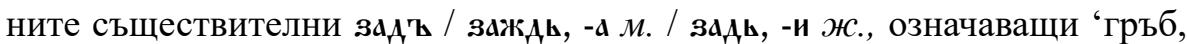

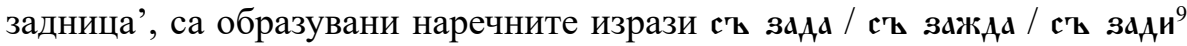

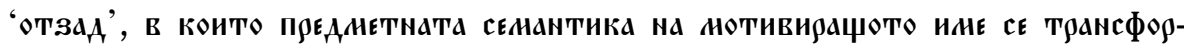

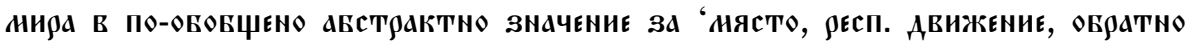

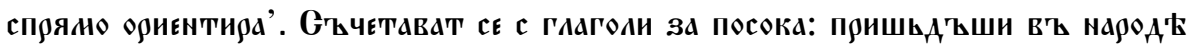

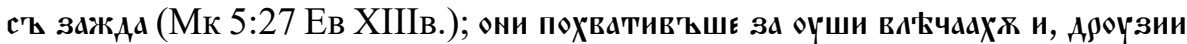

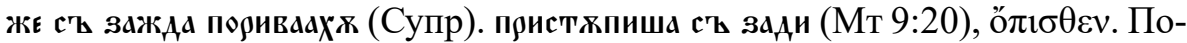
сочените изрази се срещат и в несамостойна препозиционална употреба като наречия за място с притежателно значение, съчетани с име в р.п. или

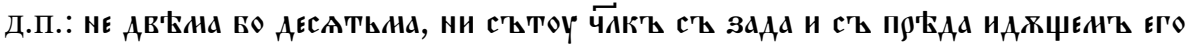
(Златоструй). Антонимизират се със съответните предложно-именни съчетания с предлозите въ и ма, нвб. ø. Срв. иззад, отзад, изотзад - случай на вторична адвербиализация с плеонастично натрупване на предлози.

Идентични в структурно-семантично отношение с наречията ст задd

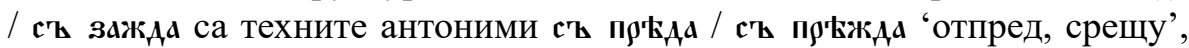

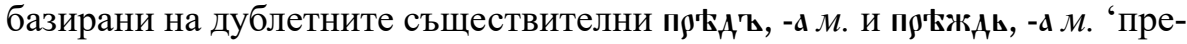

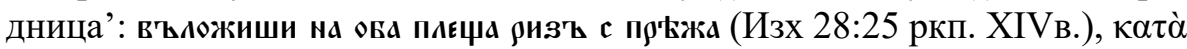

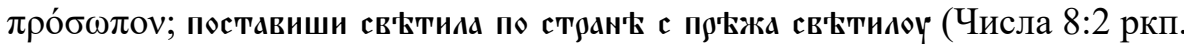
XIVв.), нвб. срв. оспреди, оспрет (от * от с преди / пред - случай на вторична адвербиализация с плеонастично натрупване на предлози).

Към групата на лексикализираните предложно-именни слияния, мотивирани от съществителни имена - наименования на телесни части, принадлежи и изразът съ лица 'против, пред'. Същият се употребява несамостойно в съчетание с име в р.п. за притежание, конкретизиращо ориентиращия предмет, т.е. като несъщински предлог: съ иица єгиптови

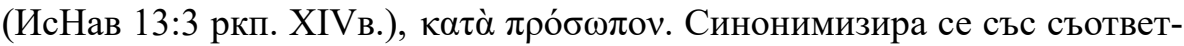
ното съчетание на предлога от'қ.

Допълнителна вторична промяна на адвербиалното значение с обстоятелствен признак към качествено-определителна семантика се наблюдава при лексикализираната предложно-именна синтагма на предлога ст и съществителното странд, засвидетелствано в значенията:

9 При съзади може да се предположи и индиректна мотивация през междинната адвербиализирана падежна форма зади. 


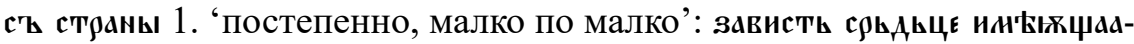

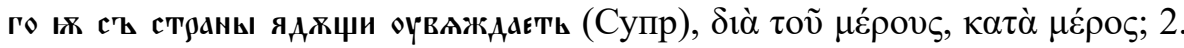

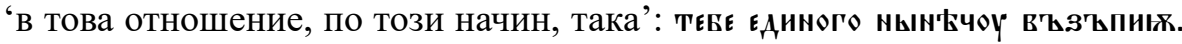

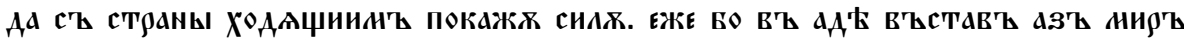
вьсь вьставъыж (Супр), нвб. Ø.

Лексикализираната предложно-именна синтагма с`z cs'九д 'отзад, из-

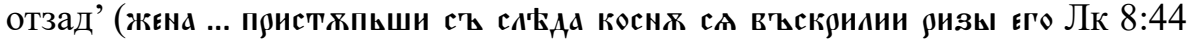
Мар, о̋ $л 1 \sigma \theta \varepsilon v)$ възхожда към съществителното сл'дық в значение 'следа, нещо, което е останало подир придвижването на предмета'. И тук при адвербиализацията на израза се наблюдава промяна в семантиката на мотивиращото съществително от по-конкретно към по-обобщено абстрактно значение на 'място, разположено отзад спрямо ориентира', нвб. ø.

С предлог съ и мотивираща дума наречие в срв. степен са образувани идентичните в структурно-семантично отношение антоними стмнкже 'отдолу' и съььшш 'отгоре, от небесата, от Бога' - с вторично конкретизиране на значението откъм субектна отнесеност. Съчетават се с глаголи за движение или положение, както и с такива, означаващи зрително въз-

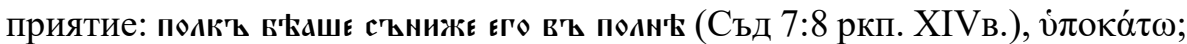

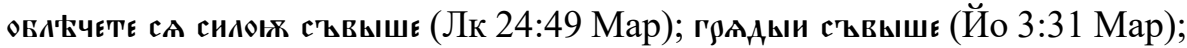

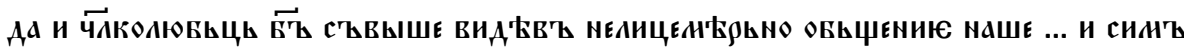
Благыид'ъ ны с'ъподовит'Қ (КлОц).

Синоним на съвышє е адвербиализираният предложен израз сқвыспрь, получен от сливането на предлога съ с наречието выспюь (от *wb-iz-prb със значение на местонахождение 'горе, високо').

От сливане на предлога съ и наречието пюћкы се е получило производното наречие съпюқкы. Има несамостойна препозиционална употреба в съчетание с име в р.П.: прияты жє съпюћкы стегна (Бт 32:25 ркП. XIVв.),

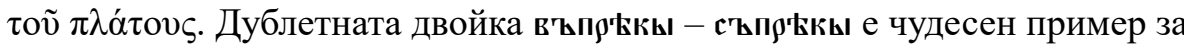
това как новите семантични връзки на предлозите в състава на производните наречия могат да доведат до синонимизиране на дериватите на препозиции с иначе противоположна семантика.

Лексикализираният предложен израз съ высока 'отвисоко’ е базиран вьрху минало през етапа на междинна субстантивация прилагателно за означаване на пространствен признак в изходно съчетание с елипса на определяе-

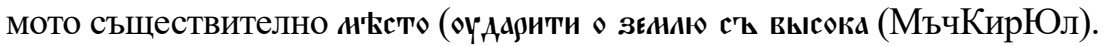




\section{2. Наречия за време}

Предлогът съ при тези наречни изрази се употребява за означаване на крайните предели на времева продължителност, за посочване на изходен момент. Съчетава се с пълнозначна дума, назоваваща пряко времево

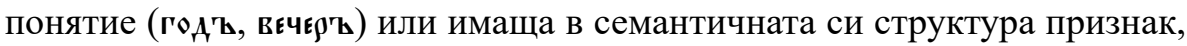
близък до признаците за време:

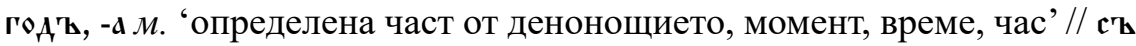

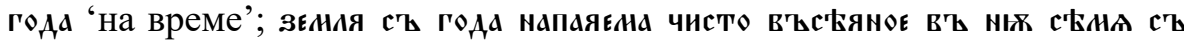
привытк'ъд'ъ в'ъзврачаєть (ПАХІв. / ПандАнтХІв./), нвб. срв. сгода.

вєчєртا, - $\boldsymbol{\alpha}$. 'вечер, времето преди настъпването на нощта, когато се смрачава' // съ вєчєра 'вечерта, с настъпването на вечерта': съь вєчєра идж-

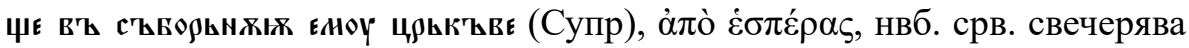
ce.

Преносно за изразяване на неопределена, но голяма отдалеченост във времето 'искони, от древност, отначало' се използват и наречията съвьышє и ст гөяы с първично пространствено значение 'отвисоко': яко вєт"ъх’

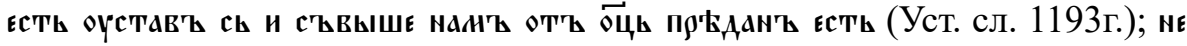

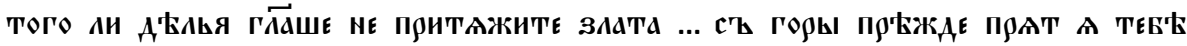

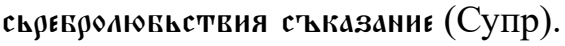

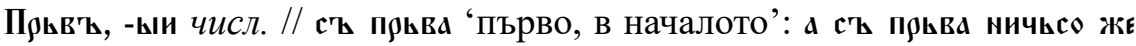

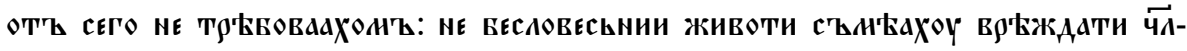
ка (Изб1073г.). Още един пример за това как новите семантични връзки на предлозите в състава на производните наречия могат да доведат до синонимизиране на дериватите на препозиции с иначе противоположна семантика ни дават лексикализираните наречни изрази въпюьвою - $\mathbf{c} \mathbf{s}$ Прьва - из' прьва.

В заключение можем да обобщим, че анализираните групи лексикализирани предложно-именни синтагми, образувани с предлозите изт, отт и съ са твърде многообразни по отношение на принадлежащите им производни. Те обединяват наречия за място, време, качество и количество, с мотивираща основа име (сыществително, прилагателно, числително), местоимение, предлог или друго наречие. Словообразувателната структура на мотивиращата основа в някои лексикални единици като искони и

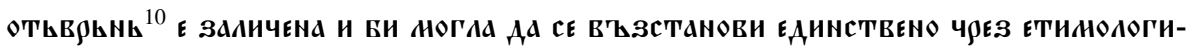

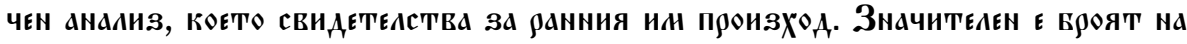

${ }_{10}$ От ие. ${ }^{*}$ wer-, *wor-, *wbr- (БЕР 1, 178). 


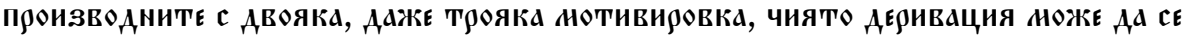
ИЗВЕАЕ ЕАНАКВО АОГИЧНО КАКТО АН९ЕКТНО ОТ ИЗХОАНОТО СЪЧЕСТВИТЕАНО, ТАКА И

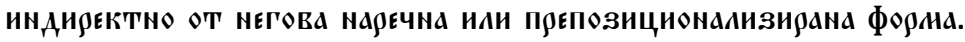

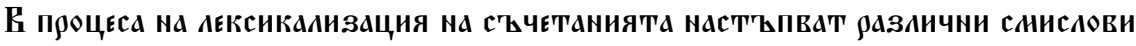

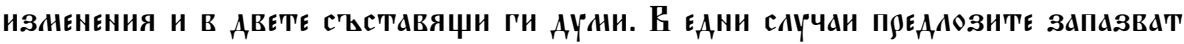
ИЗНАЧААНОТО СИ ПЛОСТ ЛАНСТВЕНО ЗНАЧЕНИЕ ЗА ОТАЕАЯН, АОКАТО В АЯУГИ ИЗГУББАТ

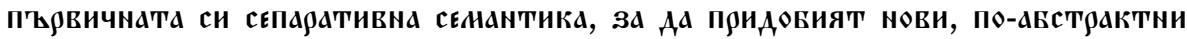

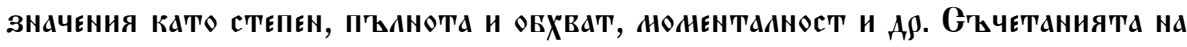

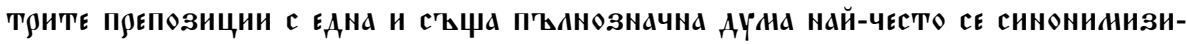

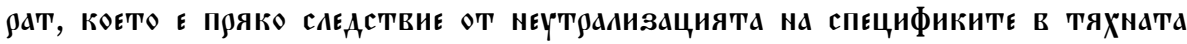
сєнантика - изъ за означаване посока на действието отвътре навън или ограниченост на пространството; оты за място, където произтича насочено навън действие или се отдалечава, откъсва нещо; съ за отделяне от повърхността или движение отгоре надолу. В историческия развой на езика съ като предлог със сепаративно значение постепенно отстьпва мястото си на от и из (вер. и под влиянието на омонимията си с комуникативното $c$ ). Отмирането му личи и по континуантите на адвербиализираните предложно-именни синтагми в съвременния български език, при които се наблюдава отпадане от синонимния ред най-често именно на дублета, образуван чрез предлог сқы, или пък вторична адвербиализация с плеонастично натрупване на предлози с цел обновяване на избледнялото вече значение на предлога съ от изходния наречен израз (особено разпространено в диалектите).

В някои случаи функцията на предлога може да се определи като обновителна, без да привнася промяна в значението (вж. извъмнддюу, извъмоу отъ овокдоу). Пример за това как новите семантични връзки на предлозите в състава на производните наречия могат да доведат до синонимизиране на дериватите на препозиции с иначе противоположна се-

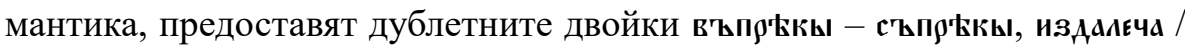

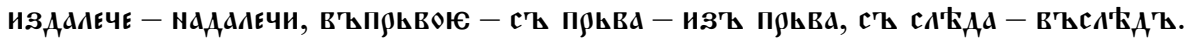

От своя страна, в състава на съчетанието пълнозначната дума често променя семантиката си от по-конкретна към по-обобщено абстрактна (оттолы, стввљьхоу, из А'ъноу и пр.).

Привличането на лексикален материал от запазените по късни преписи старославянски старославянски паметници, както и от такива, принадлежащи към други редакции с изразено силно влияние върху тях на старославянски език, обогатяват групата на наречните изрази със сепаративен предлог с нови членове, незасвидетелствани в класическия кор- 
пус, някои от които в качеството си на синоними и антоними на вече известните ни от най-старите писмени паметници, допълват семантичната парадигма на редица от познатите ни адвербиални съчетания с нерегистрирани в КСП значения.

В рамките на анализираната група наречни и полунаречни синтагми синонимията и дублетността са широко застъпени. Синонимизират се:

a) адвербиални изрази със сепаративен предлог и мотивиращи думи, съотнасящи се помежду си като еднокоренни морфологични дублети (подведени по различни склонитбени основи): испода - исподн; с $\mathbf{z}$ задd -

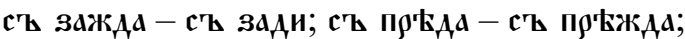

б) адвербиални изрази с един и същ сепаративен предлог и различни форми на една пълнозначна дума: издтри - изжт $\rho \mathbf{~ ; ~ и з д а в ь н а ~ - ~ и з д а в ь н о ; ~}$

в) адвербиални изрази с една и съща мотивираща дума и различни

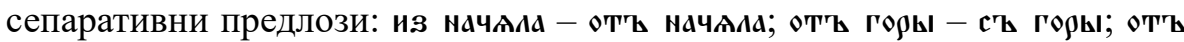
лица - с'ъ лица; с'ъ прьва - из'ъ пюьва;

г) адвербиални изрази с един и същ сепаративен предлог и различни

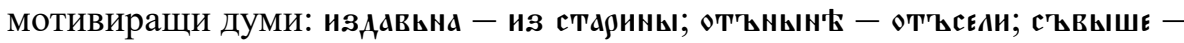

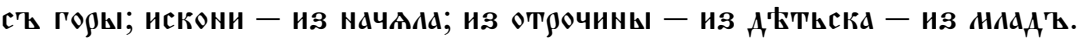

Наречията от разглежданата група имат добре изразени антонимни отношения в езика. Антонимизират се адвебиални изрази, съставени от:

а) предлози с противоположно значение и една мотивираща -

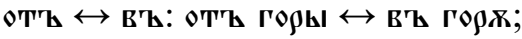

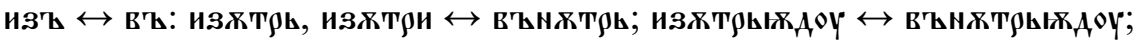

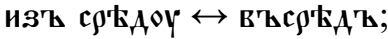

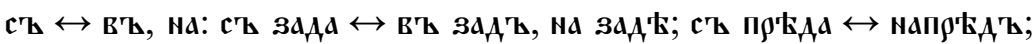

б) един предлог и мотивиращи с противоположно значение: извъноү

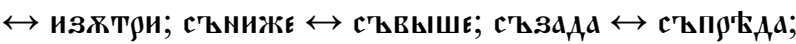

в) две противополагащи се части - предлози и мотивиращи: ст горы

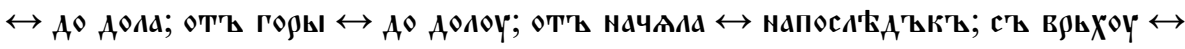
вниз'ь.

В редица случаи се натъкваме на антонимни контексти, т.е. реализация на антонимите в един и същ контекст: показд нан'ъ и тты Богон' ма-

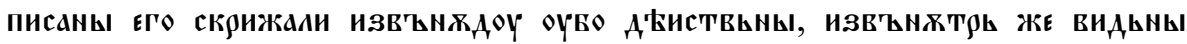

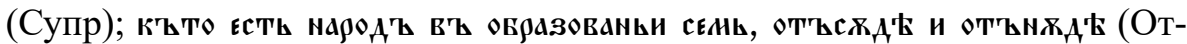

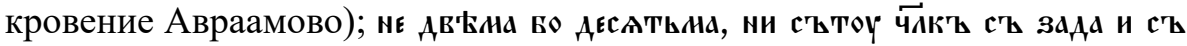
пюћдd иджщєнт єго (Златоструй).

Абстрактното значение на наречията от анализираната група, изразяващо поначало отношение, тяхната дейктичност, резултат от обобще- 
ност на субстанциалност или квалитативност, ги поставя в по-особени дистрибутивни връзки с другите думи в изречението и ги подлага на допълнителни семантични и категориални промени, включително до преминаване към сферата на служебните думи - предлози и съюзи. Така адвербиализацията, препозиционализацията и конюнкционализацията като тясно взаимосвързани транспозиционни процеси при едни и същи изходни думи се наблюдават активно не само в предписмения период на праслав. език, но и в историческия етап на писмената кодификация на старославянския език, водейки до интензивно развитие на лексикална омонимия.

Резките семантични трансформации, семантичните скокове от един категориален вид наречие в друг, на които са подложени адвербиализираните предложни съчетания, водят до развитие на полисемия, а понякога и до омонимия. Такива са категориалните преходи от наречие за място

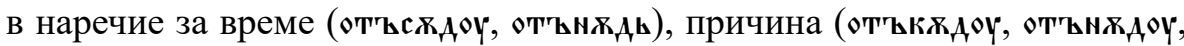

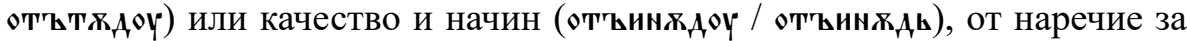
време в наречие за причина и следствие (отъсєли, отътоли) и т.н. В други случаи полисемията се развива в рамките на една и съща категория на базата на експликация на различни нейни признаци (вж. из прьва, из сиха, съъвыше, с'ъ Гө९ы).

На базата на адвербализираните предложни изрази се продуцират но-

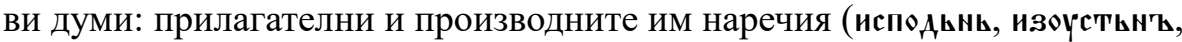

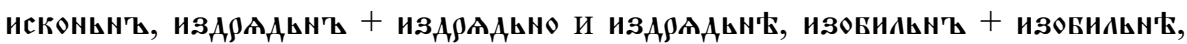

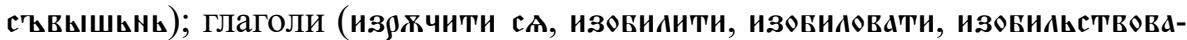

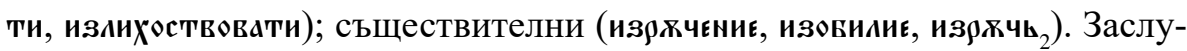
жава да се отбележи и вторичната субстантивация на някои предложно-именни синтагми като из-ненада и с-года.

Наречията от анализираните групи отговарят най-често на гр. adverbia

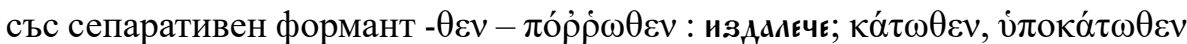

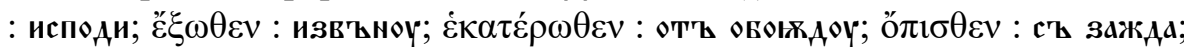

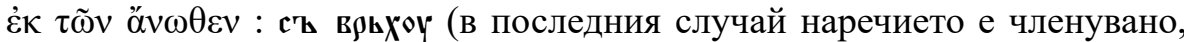
т.е. субстантивирано). Могат да стоят също срещу различни предложни

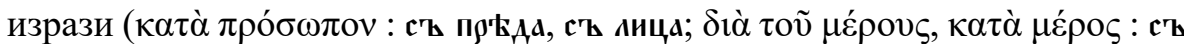

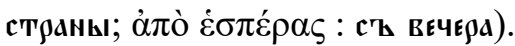

Част от основния речников фонд на съвременния български книжовен език продължават да бъдат думи и изрази като извътре, изпод, изсред, издалече, изпърво, отгоре, откъде, отначало, отсега, отчасти, свръх (при някои пълнозначната дума има различен флективен завършък от 
този на старославянското съответствие поради аналогия с други склонитбени модели или пък съвсем е изгубила старото си падежно окончание). ${ }^{11}$ Други днес съществуват в съчетание с различен предлог или без предлог: издола : отдолу, съпюккы : въпреки, издавьна : отдавна, изоүсты

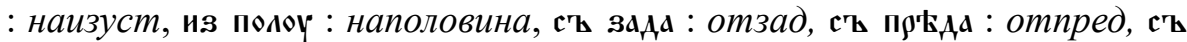
вєчєл : вечерта, надвечер, привечер. За трети се използват дублетни наречия с аналогична семантика от прилагателни имена - изржчь : ръчно, издялдь : изрядно, изокиль : изобилно. Стилистично маркирани са свише, искони, отвека, отколе, отсъд, отсъде, отнюд, оттъд, откъд, оттога, оздол. Има и лексикални единици, които са напълно отпаднали - изница,

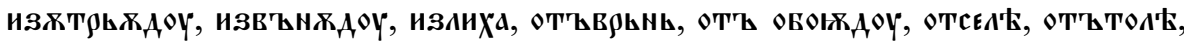

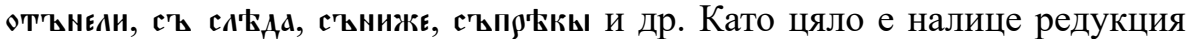
на дублетите в нвб. език. Така от дублетните редици из овила / изовиль /

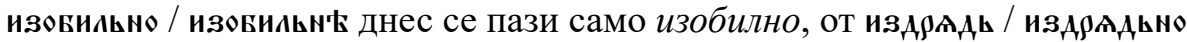
/ изд९Адин' само изрядно и др.

\section{ИЗТОЧНИЦИ}

БЕР = Български етимологичен речник. Т. 1. Ред. Вл. Георгиев. София: БАН, 1971; Т. 2. Ред. Вл. Георгиев. София: БАН, 1979.

РКБЕНО = Речник на книжовния български език на народна основа (върху текст на Тихонравовия дамаскин). Гл. ред. Е. И. Дьомина. София: Изд-во »В. Траянов«, 2012.

СДРЯ = Словарь древнерусского языка XI-XIVвв. В 10 т. Москва: РАН. Ин-т рус. яз., $1988 \rightarrow$.

МДРЯ = Срезневский, И. И. Материаль для словаря древнерусского языка по письменым памятникам. T. I-III, Санкт Петербург: Отд-ние рус. яз. и словесн. Имп. АН, 1893-1903. Репринт. Москва: »Книга«, 1989.

СтбР = Старобългарски речник. Т. І. София, 1999 и Т. II София, 2009. Отг. ред. Д. Иванова-Мирчева.

СC = Старославянский словарь (по рукописям X-ХІв.). Под редакцией Р. М. Цейтлин, Р. Вечерки и Э. Благовой, Москва: Изд-во »Русский язык«, 1999.

CЯC = Slovnik jazyka staroslověnskeho. T. I- III. Praha: AV ČR, 1958-1994.

ЦслР = Бончев, Ат. Речник на църковнославянския език. Т. 1. София: НБКМ »Св. св. Кирил и Методий«, 2002. Т. 2. София: НБКМ »Св. св. Кирил и Методий«, 2012.

11 Разбира се, континуантите логично търпят съответните системни фонетични и морфологични промени, настъпили в историята на езика. 


\section{Съкращения на средновековни паметници}

Ап 1220г. = Апостол

Ак. св. К. и М. ик. 12 = Акатист на св.св. Кирил и Методий, икос 12

Ac $=$ Асеманиево евангелие

Втз ркп. XIVв. $=$ Книга Второзаконие по ръкопис от XIVв.

ГА $/$ ХронГАм/ = Хроника на Георги Амартол

Грам. п. Нил. 1383г. =Грамота на патр. Нил Суздалски

ГрНазХІв. = 13 слова на Григорий Назиански

Ев.ХІІв. = Евангелие по ркп. от ХІІв.

Ев ХІІІв. = Евангелие по ркп. от ХІІІв.

ЕфрКрм = Ефремовска кръмча

ЕфрСир 1377г. = Паренесис на Ефрем Сирин по ркп. от 1377г.

ЖК = Житие на Константин Философ

ЖитНик /МинЧетАпр/=Житие на преп. Никита от миней-чети за м. април

ЖитНифХІІІв. = Житие на Нифонт по ркп. от ХІІІв.

ЖитСтефПерм = Житие на Стефан Пермски

Зогр $=$ Зографско евангелие

Изб1073г. = Симеонов Изборник от 1073 г.

ИпЛ = Ипатски летопис

ИполАнтихр = Слово за Антихриста на Иполит Римски

ИсНав 13:3 ркп. ХIVв. = Книга Иисус Навин по ръкопис от XIVв.

Йез ркп. XIVв. = Книга на пророк Йеремия по рькопис от XIVв.

Йер ркп. от XIV в. = Книга на пророк Йеремия по ръкопис от XIVв.

ЙоЕБ = Богословие на Йоан Екзарх

ЙоЕШ = Шестоднев на Йоан Екзарх

Клоц $=$ Клоцов сборник

КозмаИнд = Топография на Козма Индикоплов

Крм $\quad$ Кръмча книга

Лев ркп. XIVв. = Книга Левит по ръкопис от XIVв.

Map = Мариинско евангелие

Мин1096г. = Служ. миней за м. септември по ркп. от 1096 г.

Мин1097г. = Служ. миней за м. ноември по ркп. от 1097 г.

МъчКирЮл = Мъчение на св.св. Кирик и Юлита

Мъчение на Тадей /МинЧетФевр/ = Мъчение на Тадей в миней-чети за м. февруари

НестЖитТеод = Житие на преп. Теодосий от монах Нестор

ПНЧ = Пандекти на Никон Черногорец

ІНовгЛ = Пьрви Новгородски летопис

Остр = Остромирово евангелие

ПАХІв. /ПандАнтХІв./ = Пандекти на Антиох по ръкопис от ХІв.

ПАХІІ-XIIIв. = Пандект на Антиох по ркп. от XII-XIIIв.

ПатПеч $=$ Печерски патерик

ПатСинХІв. = Синайски патерик по ркп. от ХІв.

ПВЛ = Повест за отминалите години 
Прол. февр. 22 = Пролог за 22-и февруари

Прол. март $31=$ Пролог за 31-и март

Прол. май $11=$ Пролог за 11-и май

Прол. окт. 8 = Пролог за 8-и октомври

Прол. ноем. 4 = Пролог за 4-и ноември

Прол. дек. 6 = Пролог за 6-и декември

Сав $=$ Савина книга

СбГрII = Сборник държавни грамоти, т. II

Син $=$ Синайски псалтир

Супр $\quad$ Супрасълски сборник

Тп. $=$ Типик

Уст. сл. 1193г. = Цьрковен устав след 1193 г.

Четириев. 1144г. = Четириевангелие от 1144 г.

Числа ркп. XVв. = Книга Числа по ркп. от XVв.

ЮрЕв сл. 1119 г. = Юриевско евангелие след 1119 г.

\section{Съкращения на библейски книги}

$\begin{array}{ll}\text { Бт } & =\text { Книга Битие } \\ \text { Изх } & =\text { Книга Изход } \\ \text { Лев } & =\text { Книга Левит } \\ \text { Втз } & =\text { Второзаконие } \\ \text { ИсНав } & =\text { Книга Иисус Навин } \\ \text { Съд } & =\text { Книга Съдии } \\ \text { ІІІЦаре } & =\text { Трета Книга Царства } \\ \text { Пс } & =\text { Книга Псалтир } \\ \text { Песен } & =\text { Книга Песен на песните } \\ \text { Сир } & =\text { Книга на Иисус син Сирахов } \\ \text { Ис } & =\text { Книга на прор. Исая } \\ \text { Йер } & =\text { Книга на прор. Йеремия } \\ \text { Йез } & =\text { Книга на прор. Йезекиил } \\ \text { Дан } & =\text { Книга на прор. Даниил } \\ \text { ІМак } & =\text { Пьрва книга на Макавеите } \\ \text { Мк } & =\text { Евангелие според Марк } \\ \text { Лк } & =\text { Евангелие според Лука } \\ \text { Йо } & =\text { Евангелие според Йоан } \\ \text { ІІКор } & =\text { Второ послание до коринтяните }\end{array}$

\section{Лексикографски съкращения}

$\begin{array}{ll}\text { гр. } & =\text { грьцки } \\ \text { диал. } & =\text { диалектно } \\ \text { д.п. } & =\text { дателен падеж }\end{array}$




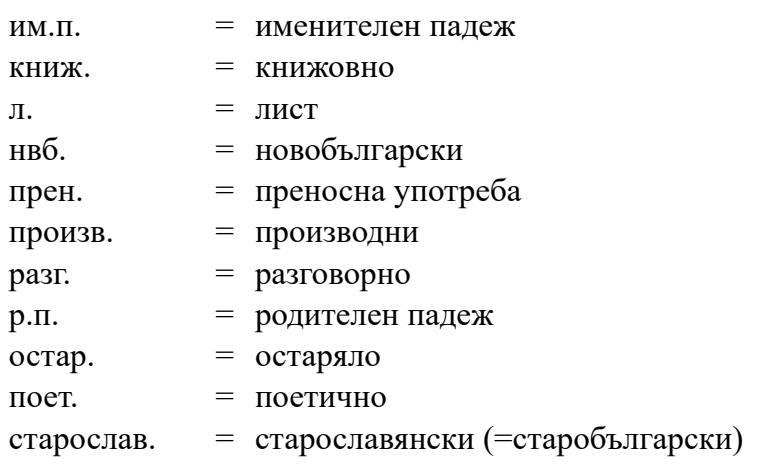

\section{ЛИТЕРАТУРА}

AITZETMÜLLER, R. 1978. Altbulgarische Grammatik als Einführung in die slavische Sprachwissenschaft. Freiburg im Breisgau: U.W.Weiher.

BORKOVSKIJ; KUZNECOV 1963. = БОРКОВСКИ, В. И.; П. С. КУЗНЕЦОВ 1963. Историческая грамматика русского языка. Москва: АH CCCP. [BORKOVSKIJ, V. I; P. S. KUZNECOV 1963. Istoričeskaja grammatika russkogo jazyka. Moskva: AN SSSR].

BUSLAEV 1959. = БУСЛАЕВ, Ф. И. 1959. Историческая грамматика. Москва: Учпедгиз. [BUSLAEV, F. I. 1959. Istoričeskaja grammatika. Moskva: Učpedgiz].

ČURMAEVA 1980. = ЧУРMAEBA, Н. В. Описание наречий в историческом словаре. В: Древнерусский язык. Лексикология и лексикография. Москва: »Наука«, 60-78. [ČURMAEVA, N. V. 1980. Opisanie narečij v istoričeskom slovare. Drevnerusskij jazyk. Leksikologija i leksikografija. Moskva: »Nauka«, 60-78.]

DOBREV 1982. = ДОБРЕВ, И. Старобългарска граматика. Теория на основите. София: Изд-во »Наука и изкуство«. [Starobălgarska gramatika. Teorija na osnovite. Sofija: Nauka i izkustvo].

DORITSCH, A. 1910. Gebrauch der altbulgarischen Adverbia. Leipzig: Johann Ambrosius Barth.

EFIMOVA 1989.а. = ЕФИМОВА, В. С. 1989.а. О значений наречий вєльди, нъъного и з‡лю в языке старославянских рукописей. Этимология, 1986-1987. Москва. [О značenij narečij vel'mi, mnogo i zělo v jazyke staroslavjanskih rukopisej. Ėtimologija.]

EFIMOVA 1989.b. = ЕФИМОВА, В. С. 1989.б. Наречия в языке старославянских рукописей. Диссертация на соискание ученой степени канд. филол. наук. Москва. [EFIMOVA, V. S. 1989.b. Narečija v jazyke staroslavjanskih rukopisej. Dissertacija na soiskanie učenoj stepeni kand. filol. nauk. Moskva.]

EFIMOVA 1989.c. = ЕФИМОВА, В. С. 1989.ц. О старославянских наречиях, мотивированных существительными. Советское славяноведение 2: 74-84. [EFI- 
MOVA, V. S. 1989.c. O staroslavjanskih narečijah, motivirovannyh suštestvitel'nymi. Sovetskoe slavjanovedenie 2: 74-84.]

EFIMOVA 1991.a. = ЕФИМОВА, В. С. 1991.а. Старославянские отъадъективные наречия с суфиксом -ъ. Советское славяноведение 3: 71-80. [EFIMOVA 1991.а. Staroslavjanskie ot'ad'ektivnye narečija s sufiksom -ě. Sovetskoe slavjanovedenie 3: 71-80.]

EFIMOVA 1991.b. = ЕФИМОВА, В. С. 1991.б. Об употреблении непроизводных наречий в языке старославянских рукописей. Palaeobulgarica XV/2: 32-36. [EFIMOVA 1991.b. Ob upotreblenii neproizvodnyh narečij v jazyke staroslavjanskih rukopisej. Palaeobulgarica XV/2: 32-36.]

EFIMOVA 2006. = ЕФИМОВА, В. С. 2006. Старославянская словообразовательная морфемика. Москва: Институт славяноведения РАН. [EFIMOVA, V. S. 2006. Staroslavjanskaja slovoobrazovatel'naja morfemika. Moskva: Institut slavjanovedenija RAN.]

GEORGIEV 1976. = ГЕОРГИЕВ, СТ. 1976. Система на наречието в съвременния български книжовен език. Дис. за получаване на научната степ. »Доктор на филологическите науки«. София. [GEORGIEV, St. 1976. Sistema na narečieto v săvremennija bălgarski ezik. Dis. za polučavane na naučnata stepen »Doktor na filologičeskite nauki«. Sofija.]

HARALAMPIEV 1980. = ХАРАЛАМПИЕВ, ИВ. 1980. Качествените наречия на -о и -Ђ в произведенията на Евтимий Търновски. Трудове на ВТУ „Кирил и Методий«. T. 15, кн. 2. София: Унив. изд., 111-135. [HARALAMPIEV, Iv. 1980. Kačestvenite narečija na -o i -ě v proizvedenijata na Evtimij Tărnovski. Trudove na VTU »Kiril $i$ Metodij«. T. 15, kn. 2. Sofija: Univ. izd., 111-135.]

DURIDANOV 1993. = ДУРИДАНОВ, Ив. et al. 1993. Граматика на старобългарския език. Фонетика, морфология, синтаксис. Ив. Дуриданов (гл. ред.). София: БАН, 314-324. [DURIDANOV, Iv. et al. 1993. Gramatika na starobălgarskija ezik. Fonetika, morfologija, sintaksis. Gl. red. I. Duridanov (gl. red.). Sofija: BAN, 314-324.]

JAN 1967. = ЯН, Я. 1967. Старославянское наречие как член предложения. Slavia XXXVI/1: 1-23. [JAN, Ja. 1967. Staroslavjanskoe narečie kak člen predloženija. Slavia $X X X V I / 1: 1-23$.

KUZNECOV 1956. = КУЗНЕЦОВ, П. С. 1956. Историческая грамматика русского языка /морфология/. Москва: »КомКнига«. [KUZNECOV, P. S. 1956. Istoričeskaja grammatika russkogo jazyka /morfologija/. Moskva: »KomKniga«.]

LESKIEN, A. 1919. Grammatik der altbulgarischen (altkirchenslavischen) Sprache. Heidelberg: C. Winter.

LUNT, H. G. 1955. Old Church Slavonic grammar. Slavistic Printings and Reprintings III. (Cornelius H. van Schooneveld (ed.). 's-Gravenhage: Mouton \& Co.

MEILLET, A. 1951. Linguistique historique et linguistique générale, Volume 2. Paris: Klincksieck.

MIKLOŠIČ 1899. = МИКЛОШИЧ, Ф. 1899. Сравнительная морфология славянских языков. Вып. 2, Москва: Университетская типография. [MIKLOŠIČ, F. 1899. 
Sravnitel'naja morfologija slavjanskih jazykov, Vyp. 2. Moskva: Universitetskaja tipografija.]

MILETIC̆ 1946. = МИЛЕТИЧ, Л. 1946. Старобългарска граматика (синтаксис). София: Целгра. [MILETIČ, L. 1946. Starobălgarska gramatika (sintaksis). Sofija: Celgra.]

MIRČEV 1963. = МИРЧЕВ, К. 1963. Историческа граматика на българския книжовен език. София: »Народна просвета«. [MIRČEV, K. 1963. Istoričeska gramatika na bălgarskija knižoven ezik. Sofija: »Narodna prosveta«.]

MOSZYŃSKI, L. 1976. Starosłowianskie *perdъ - *perdь. Zeszyty naukowe wydziału humanistycznego. Filologia polska. Prace językoznawcze Un-tu Gdańskiego 1976/4: 124.

SLAVOVA 2017. = СЛАВОВА, Т. 2017. Старобългарски език. Университетски учебник. София: УИ »Св. Кл. Охридски«. [SLAVOVA, Т. 2017. Starobălgarski ezik. Universitetski učebnik. Sofija: UI »Sv. Kl. Ohridski«.]

ŠANSKIJ 1968. = ШАНСКИЙ, Н. М. 1968. Очерки по русскому словообразованию. Москва: Учпедгиз, 1968. [ŠANSKIJ, Н. М. 1968. Očerki po russkomu slovoobrazovaniju. Moskva: Učpedgiz.]

VAJAN 1952. = ВАЯН, А. Руководство по старославянскому языку. Москва: Иностранная литература. [VAJAN, A. 1952. Rukovodstvo po staroslavjanskomu ja$z y k u$. Moskva: Inostrannaja literatura].

VELČEVA 1964. = ВЕЛЧЕВА, Б. Показателни местоимения и наречия в новобългарските паметници от XVII-XVIIIв. Известия на Института за български език. Кн. 10. София, 159-235. [VELČEVA, B. 1964. Pokazatelni mestoimenija i narečija v novobălgarskite pametnici ot XVII-XVIIIv. Izvestija na Instituta za bălgarski ezik. Kn. 10. Sofija, 159-235]. 
S a ž et a k

Tatjana Ilieva

\section{POPRILOŽNJENJE I POPRIJEDLOŽNJENJE PRIJEDLOŽNIH SKLOPOVA U STAROSLAVENSKOM JEZIKU \\ PRILOŽNI I POLUPRILOŽNI IZRAZI TVORENI PRIJEDLOZIMA SA ZNAČE- NJEM ODVAJANJA}

Predmet istraživanja u članku su priložni i polupriložni izrazi (s nepotpunom leksikalizacijom), nastali spajanjem prijedloga s punoznačnom riječju u srednjovjekovnom staroslavenskom jeziku. Studija je strukturirana na principu klasifikacije, kategorizirajući empirijski materijal prema različitim kriterijima - prvo u skupinama prema prijedlozima uključenima u tvorbu riječi, unutar svake pojedinačne skupine - prema semantici koju novooblikovani priložni ili polupriložni izraz ima (za mjesto, vrijeme, način, količinu, uzrok) i na kraju - na temelju leksičko-gramatičke pripadnosti motivirajuće riječi (imenica, pridjev, broj, prilog, prijedlog). U svakom se slučaju analizira put popriložnjenja i prate se sustavni odnosi novooblikovane priložne jedinice. Ključne riječi: staroslavenski jezik, leksičko-sintaktička tvorba riječi, popriložnjenje

Sum mary

Tatjana Ilieva

\section{ADVERBIALIZATION AND PREPOSITIONALISATION OF PREPOSITIONAL PHRASES IN OLD BULGARIAN \\ ADVERBIAL AND SEMI-ADVERBIAL PHRASES WITH SEPARATIVE PREPOSITIONS}

The topic of research in this paper are the adverbial and semi-adverbial phrases (with incomplete lexicalization), which derive from the adhesion of a preposition to a lexical word in the medieval Old Slavonic language. The empirical material is systematized on the basis of prepositions involved in word formation, in view of the adjunct determined by the newly-formed adverbs and on the basis of the lexico-grammatical affiliation of the motivating word. The adverbialization path is analyzed in each case and the systematic relations of the newly-formed adverbial unit are tracked.

K e y w or d s : Old Slavonic language, lexical and syntactic word formation, adverbialization

Tatyana Ilieva

Cyrillo-Methodian Research Center at the BAS

Sofia (Bulgaria)

ilieva_tatyana@abv.bg 